\title{
(2) norden
}

\section{Ihmiskauppa ja työelämä}

Pohjoismainen konferenssi 27-28.11.2012, Helsinki
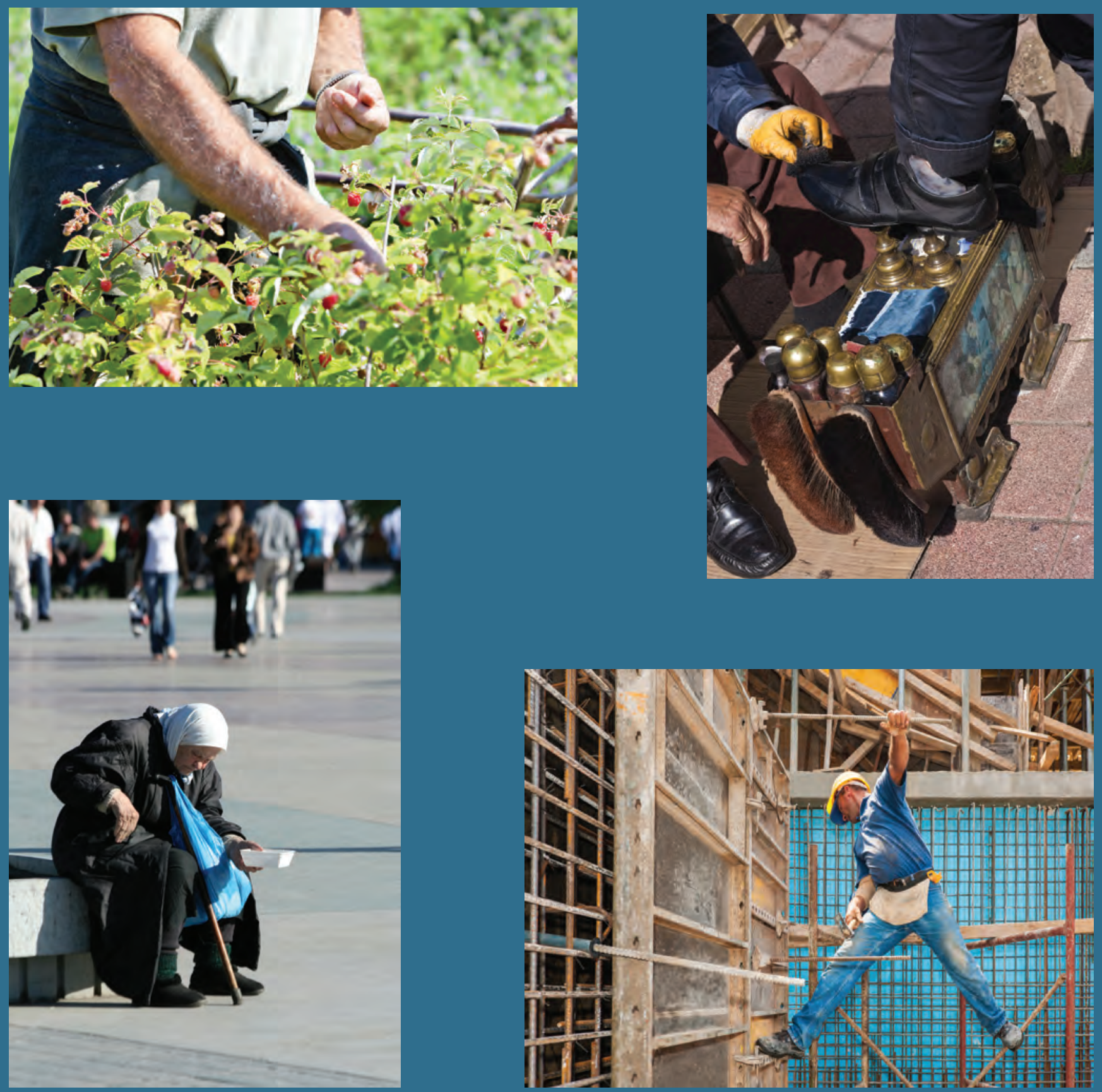

4 norden 



\section{Ihmiskauppa ja työelämä}

Pohjoismainen konferenssi

27-28.11.2012, Helsinki 
Ihmiskauppa ja työelämä

Pohjoismainen konferenssi 27-28.11.2012, Helsinki

ISBN 978-92-893-2592-9

http://dx.doi.org/10.6027/TN2013-556

TemaNord 2013:556

(C) Pohjoismaiden ministerineuvosto 2013

Ulkoasu: Hanne Lebech

Kannen valokuva: ImageSelect

Valokuva: Matti Keränen

Pohjoismaiden ministerineuvosto on myöntänyt tukea raportin julkaisemiseen. Raportin sisältö ei välttämättä edusta Pohjoismaiden ministerineuvoston kantaa, näkemyksiä tai suosituksia.

www.norden.org/fi/julkaisut

\section{Pohjoismainen yhteistyö}

Pohjoismainen yhteistyö on yksi maailman laajimpia alueellisia yhteistyömuotoja. Yhteistyön piiriin kuuluvat Islanti, Norja, Ruotsi, Suomi ja Tanska sekä Ahvenanmaa, Färsaaret ja Grönlanti.

Pohjoismaista yhteistyötä tehdään politiikan, talouden ja kulttuurin aloilla tärkeänä osana eurooppalaista ja kansainvälistä yhteistyötä. Pohjoismaisen yhteisön tavoitteena on vahva Pohjola vahvassa Euroopassa.

Pohjoismainen yhteistyö pyrkii vahvistamaan pohjoismaisia ja alueellisia etuja ja arvoja globaalissa maailmassa. Maiden yhteiset arvot lujittavat osaltaan Pohjolan asemaa yhtenä maailman innovatiivisimmista ja kilpailukykyisimmistä alueista.

\section{Pohjoismaiden ministerineuvosto}

Ved Stranden 18

DK-1061 København K

Puhelin (+45) 33960200

www.norden.org 


\section{Sisältö}

Yhteenveto

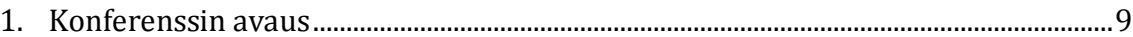

1.1 Ihmiskauppa - mikä on pakko, mitä on hyväksikäyttö?

Vähemmistövaltuutettu ja kansallinen ihmiskaupparaportoija

Eva Biaudet, Suomi

2. Istunto I Työvoiman rekrytointi Pohjoismaihin........................................................ 15

2.1 Sairaanhoitajien rekrytointi Ullevålin sairaalaan Oslossa............................... 16

2.2 Ulkomaalaiset marjanpoimijat Suomessa ....................................................... 17

2.3 Au-paireihin ja siivousalaan kohdistuva ihmiskauppa - riskit, rekrytointi ja välittäjät...................................................................................... 18

$2.4 \quad$ Kommenttipuheenvuoro ................................................................................. 19

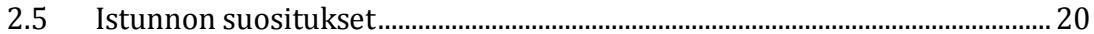

3. Istunto II Ihmiskaupan ja työvoiman hyväksikäyttö Pohjoismaissa ......................... 21

3.1 Ihmiskauppiaat - veroviraston toimet ihmiskauppaa vastaan...................... 22

3.2 Ammattiyhdistysten toimet työmarkkinoilla tapahtuvaa

ihmiskauppaa vastaan Pohjoismaissa............................................................... 23

3.3 Työvoiman hyväksikäyttö Suomessa työsuojelun näkökulmasta ................ 24

3.4 Kommenttipuheenvuoro ..................................................................................... 25

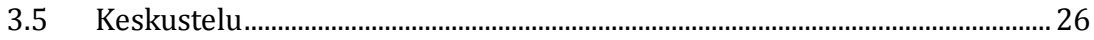

3.6 Istunnon suositukset............................................................................................. 26

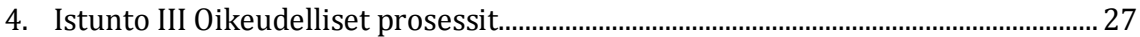

4.1 Norjalainen oikeustapaus - syyttäjän ja poliisin välinen yhteistyö ............. 28

4.2 Ihmiskauppa marjanpoimijoilla - marjanpoimijoiden rekrytointi

Ruotsiin

4.3 Työperäinen ihmiskauppa - esitutkinnan ja prosessin haasteet syyttäjän näkökulmasta ................................................................................... 32

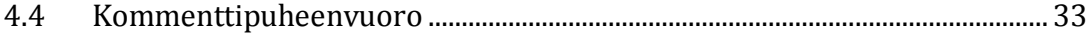

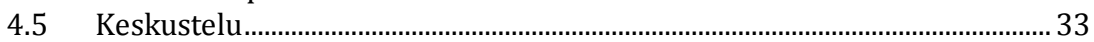

4.6 Istunnon suositukset............................................................................................ 34

5. Istunto IV Noudattavatko Pohjoismaat omia oppejaan? ..............................................35

5.1 Unelma koulutuksesta ja työstä ......................................................................... 36

5.2 Kuka tulee työskentelemään Ruotsiin? ............................................................. 36

5.3 Uhrien harkinta-ajat - kokemuksia seitsemästä maasta ................................... 37

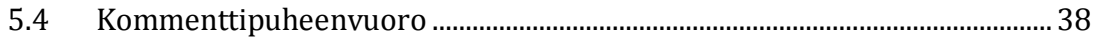

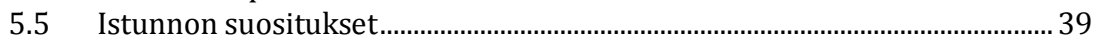

6. Istunto V Paneelikeskustelu Yhteistyötä yli rajojen ja sektoreiden ........................... 41

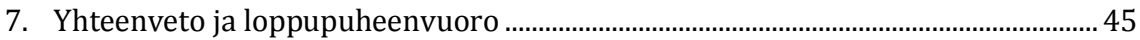

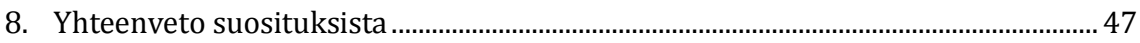

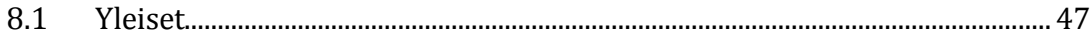

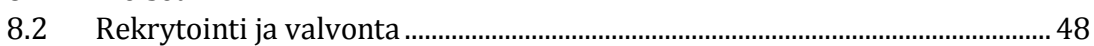

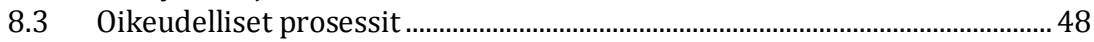

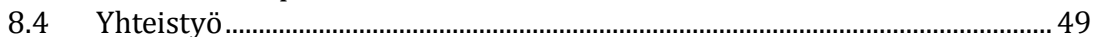


Sammanfattning ..

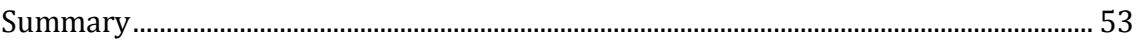

9. Liite 


\section{Yhteenveto}

Pohjoismainen konferenssi Ihmiskaupasta ja työelämästä järjestettiin Helsingissä 27-28.11.2013. Konferenssissa käsiteltiin monialaisesta näkökulmasta ihmisen joutumista ihmiskaupan uhriksi etsiessään töitä muusta maasta. Konferenssin tavoitteena oli välittää tietoa eri toimijoiden osaamisesta, rooleista ja vastuusta sekä kyvystä tunnistaa ja käsitellä työperäiseen ihmiskauppaan liittyviä ongelmia.

Suurin haaste tänään Pohjoismaissa ihmiskaupan vastaisessa työssä toimiville on tunnistaa ne naiset, miehet, tytöt ja pojat, jotka ovat työperäisen ihmiskaupan uhreja. Ihmiskaupan uhrien on saatava tietoa oikeuksistaan ja sosiaalisista palveluista, joita on saatavilla. Konferenssissa esiteltiin käytännön esimerkkejä siitä, miten pohjoismaat, poliisi, syyttäjä, tuomioistuin, työsuojeluviranomaiset, työmarkkinatahot ja kansalaisjärjestöt työskentelevät työperäisen ihmiskaupan parissa.

Konferenssin lähtökohtana olivat tulokset aiemmista ihmiskaupan ja työelämän konferensseista sekä projekteista, joita pohjoismaiset viranomaiset ja järjestöt ovat järjestäneet viime vuosina.

Konferenssin aikana käsiteltäviä tärkeitä kysymyksenasetteluja olivat:

- Mikä on työhön pakottamisen ja joidenkin maahanmuuttajien huonojen työehtojen kohtaamisen välinen ero?

- Mikä on suurin haaste liittyen ihmiskaupan uhrien tunnistamiseen työmarkkinoilla?

- Miten työsuojelu voi myötävaikuttaa?

- Kuinka yhteistyötä viranomaisten ja työmarkkinoiden osapuolten välillä voidaan tehostaa? Mitkä ovat suurimmat haasteet?

- Onko sosiaalisia palveluita mukautettu uhrien tarpeisiin?

- Mitä voidaan saavuttaa pohjoismaisella yhteistyöllä? 
Konferenssin aikana järjestettiin:

- Avausistunto

- Neljä teemaistuntoa:

Pohjoismaihin - työvoiman rekrytointi, Ihmiskauppa - työvoiman

hyväksikäyttö pohjoismaissa, Oikeudelliset prosessit - ihmiskauppa ja työelämä ja Noudattavatko pohjoismaat omia oppejaan?

- Paneelikeskustelu

Vähemmistövaltuutettu Eva Biaudet esitti konferenssin päätteeksi yhteenvedon.

Raportin lopusta löytyy yhteenveto kaikista konferenssin aikana esitetyistä suosituksista. Lisäksi jokaisen alustajan esittämät suositukset löytyvät vielä erikseen hänen alustuksensa yhteydessä.

Konferenssi keräsi suuren määrän osanottajia eri maista ja kansainvälisistä ja kansallisista järjestöistä. Konferenssiin osallistui yhteensä noin 260 osanottajaa, jotka tulivat kaikista Pohjoismaista sekä Baltian maista ja Venäjältä. Konferenssiin osallistui 70 poliisin ja rajavartiolaitoksen edustajaa. Muita osallistujaryhmiä olivat poliitikot, kansainväliset järjestöt, syyttäjät, maahanmuuttoviranomaiset, työsuojeluviranomaiset, työmarkkinajärjestöt, kansalaisjärjestöt ja tutkijat.

Konferenssin järjestäjänä toimi Vähemmistövaltuutettu, joka toimii myös Suomen kansallisena ihmiskaupparaportoijana. Konferenssin rahoitti Pohjoismaiden ministerineuvosto yhdessä Vähemmistövaltuutetun ja Pohjoismaiden neuvoston kanssa. 


\section{Konferenssin avaus}

\section{Ministeri Anna-Maja Henriksson, Oikeusministeriö, Suomi}

Oikeusministeri Anna-Maja Henriksson korosti ihmiskaupan olevan ihmisten perusoikeuksia vakavasti loukkaava rikos, minkä vuoksi on tärkeää vaihtaa kokemuksia muiden pohjoismaalaisten toimijoiden kanssa. Ihmiskauppa ei ole uusi ilmiö. Ihmiskaupan torjunta on tehostunut tämän vuosituhannen aikana. Pohjoismaat ovat mieltäneet vastuunsa ja ovat olleet aktiivisia ihmiskaupan torjunnassa.

Vaikka pohjoismainen yhteistyö on tärkeää, on muistettava että tärkeimmät toimenpiteet tapahtuvat kansallisella tasolla. Kansalliseen työhön tarvitaan sekä kansallinen riippumaton ihmiskaupparaportoija sekä toimija, joka koordinoi ja yhteen sovittaa toimintaa kansallisella tasolla.

Henriksson kehotti ryhtymään rohkeasti esitutkintatoimenpiteisiin ihmiskaupparikoksissa ihmiskauppiaiden syytteeseen saattamiseksi sekä uhrien suojelemiseksi. Hän painotti myös, että on myös täysin kansallisia ihmiskauppatapauksia, vaikka suurin osa ihmiskaupasta on rajat ylittävää.

Henriksson muistutti viranomaisten vastuusta ihmiskaupan uhrien tunnistamisessa. Tärkeinä kehitysalueina Henriksson nosti esille muun muassa työsuojelun toiminnan ja resurssit sekä viranomaisten välisen tiedonvaihdon ja yhteistyön. Tehostetun ihmiskaupan uhrien tunnistamisen edellytyksenä Henriksson mainitsi uhrien sekä muiden todistajien suojelun priorisoinnin. Tähän tarvitaan toimiva auttamisjärjestelmä, jotta uhrit voisivat irtaantua rikollisesta toiminnasta sekä heitä hyväksikäyttävistä rikollisista.

Ministeri Anna-Maja Henriksson oli sairauden takia estynyt osallistumasta ja hänen avauspuheenvuoronsa esitti erityisavustaja Robin Harms. 


\section{Pääsihteeri Halldór Ásgrímsson, Pohjoismaiden ministerineuvosto}

Pääsihteeri Halldór Ásgrímsson aloitti puheenvuoronsa sanomalla ihmiskaupan olevan ihmisoikeusloukkaus, joka kohtaa kaikista haavoittuneimpia kansalaisryhmiä. Ásgrímsson painotti, etteivät Pohjoismaat ole poikkeus ihmiskaupan esiintymisessä ja totesi, että on häpeä Pohjoismaille, että Pohjoismaissa esiintyy ihmiskauppaa ja työvoiman hyväksikäyttöä. Pakkotyö on sen sijaan suhteellisen uusi ilmiö Pohjoismaissa. Tämä edellyttää lisätietoutta ja huomiota ongelmasta. Pakkotyön torjuminen vaatii myös työmarkkinatoimijoiden aktivoitumista.

Köyhyydessä ja esimerkiksi kodittomana elävät ihmiset liikkuvat yhä enenevissä määrin yli rajojen paremman elämän toivossa. Ásgrímsson mainitsi myös vallitsevan talouskriisin yhtenä syynä siihen, että työn saanti on vaikeutunut. Tämä on lisännyt ihmisten halua ottaa riskejä.

Ásgrímsson sanoi, että Pohjoismaiden ministerineuvoston tavoitteena on torjua ihmiskaupan kaikkia muotoja. Ásgrímsson painotti voimakkaan ja hyvin koordinoidun pohjoismaisen yhteistyön merkitystä. Pohjoismaiden yhteistyöllä on pitkät perinteet ja se perustuu yhteisiin perustavanlaatuisiin arvoihin. Pohjoismaiden ministerineuvosto työskentelee vahvistaakseen alueellista yhteistyötä pohjoismaisella tasolla, mutta myös Baltian maiden ja Luoteis-Venäjän kanssa. Sisällyttämällä maita, järjestöjä ja muita ihmiskaupan vastaisia toimijoita pyritään saavuttamaan laajempi koordinointi, mikä Pohjoismaiden ministerineuvoston mukaan on edellytys rajat ylittävän rikollisuuden torjunnalle. Verkostoitumisella sekä yhteistyöllä on merkityksensä tavoitteen saavuttamiseksi. Prosessiin on otettava mukaan myös kansainväliset järjestöt.

Pääsihteeri Halldór Ásgrímsson sanoi:

\footnotetext{
"Itse asiassa voimme ratkaista ongelman, jos me kaikki otamme osaltamme vastuumme vakavasti. Meillä kaikilla on roolimme suhteessa ennaltaehkäisyyn, uhrien tukemiseen ja ihmiskauppiaiden syytteeseen saattamiseen. On tärkeä myös muistaa, että ihmiskauppaa tapahtuu, koska sille on kysyntää - etenkin vauraimmissa maissa - kuten Pohjoismaissa."
} 
Kuva 1. Pääsihteeri Halldór Ásgrímsson, Pohjoismaiden ministerineuvosto, vähemmistövaltuutettu Eva Biaudet, Suomi, erityisavustaja Robin Harms, Suomi, ja vanhempi erityisasiantuntija Maria-Pia de Palo, Pohjoismaiden ministerineuvosto osallistuivat avausistuntoon

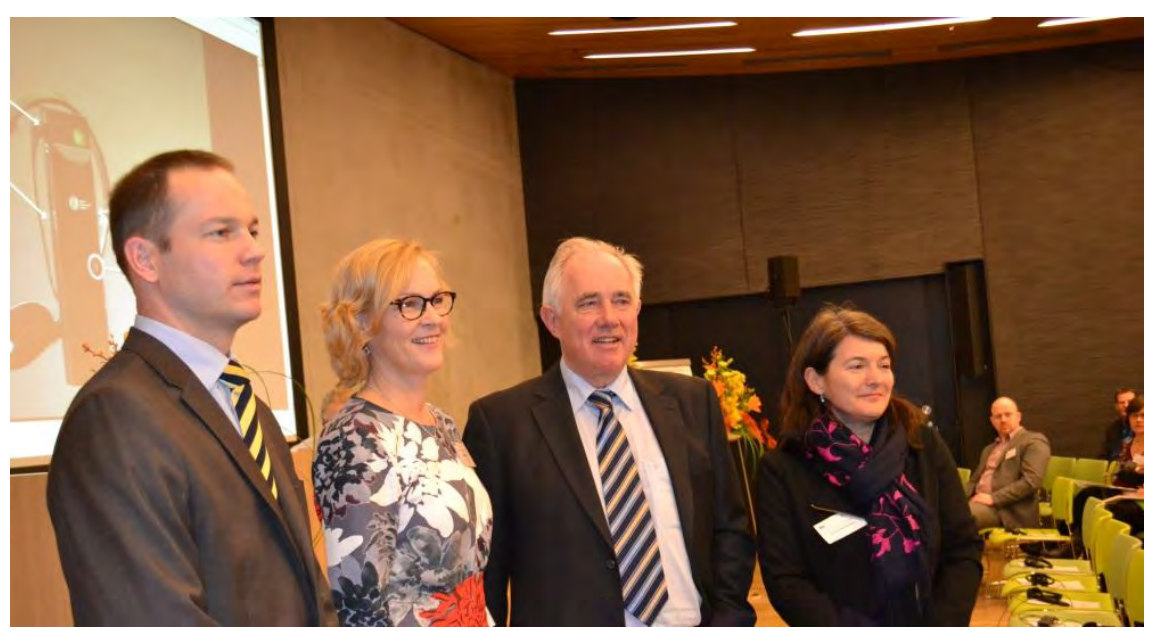

Valokuvaaja: Matti Keränen.

\section{Kansanedustaja Maria Stenberg, Eduskunta, Ruotsi, jäsen, kansalais- ja kuluttajavaliokunta, Pohjoismaiden neuvosto}

Kansanedustaja Maria Stenberg korosti avauspuheenvuorossaan ihmiskaupan olevan ihmisoikeusloukkaus, johon on suhtauduttava vakavasti. Ihmiskaupan torjumiseksi Stenberg korosti Pohjoismaiden sekä Itämeren alueen rajat ylittävän yhteistyön merkitystä.

Stenberg kertoi Pohjoismaiden neuvoston kansalais- ja kuluttajavaliokunnan jo pitempään kohdistaneensa huomionsa ihmiskauppakysymykselle sekä työskennelleensä parantaakseen yhteistyötä Pohjoismaissa ja Itämeren alueella. Ihmiskaupankaupan vastainen työ vaatii toiminnan koordinointia, joka myös edellyttää poliittista yhteistyötä.

Stenberg nosti esille Pohjoismaiden neuvoston tukeman suosituksen, joka esitettiin parlamentaarisessa itämerikonferenssissa 2011. Suosituksen mukaan on:

"tärkeä edistää toimenpiteitä, jotka luovat lisää ymmärrystä ihmiskaupasta työelämässä, käynnistää ja tukea yhdessä työmarkkinoiden ja viranomaisten kanssa yhteisiä toimintasuunnitelmia, vahvistaa oikeudellisia ja operatiivisia keinoja työperäisen ihmiskaupan tunnistamisessa ja torjunnassa sekä toteuttaa tiedotuskampanjoita ihmiskaupasta työelämässä." 
Stenberg korosti puheenvuorossaan jatkuvan trendien seuraamisen sekä ongelmiin aikaisen puuttumisen tärkeyttä. Ihmiskauppaongelman taustalla olevat syyt kuten köyhyys, konfliktit, epätasapainoinen sosiaalinen jakauma ja syrjäytyminen, ovat moninaiset sekä monimutkaiset ja vaativat kauaskantoista ennaltaehkäisevää työtä. On tärkeä että ihmiskaupparikokset tutkitaan asianmukaisesti ja että uhrien auttamiselle ja suojelemiselle on asianmukainen järjestelmä. Tämän lisäksi Stenberg korosti kansainvälisen panostuksen tärkeyttä.

\subsection{Ihmiskauppa - mikä on pakko, mitä on hyväksikäyttö? Vähemmistövaltuutettu ja kansallinen ihmiskaupparaportoija Eva Biaudet, Suomi}

Vähemmistövaltuutettu Eva Biaudet kertoi puheenvuorossaan toimenkuvastaan Suomessa kansallisena ihmiskaupparaportoijana sekä sen kautta saamista kokemuksistaan. Biaudet'n mukaan tehokas ihmiskaupan vastainen työ edellyttää sekä kansallisen ihmiskaupparaportoijan että kansallisen koordinaattorin olemassaoloa.

Biaudet totesi, että Pohjoismaissa on ihmiskauppaa, jota esiintyy tavallisilla työpaikoilla ympäri maata, maaseudulta pääkaupunkiin. Uhrit ovat useimmiten syystä tai toisesta alttiita ihmiskaupalle. Biaudet korosti, että ihmiskauppaa tulisi tästä syystä ennaltaehkäistä minimoimalla maahanmuuttajien alttiutta ihmiskaupalle eri tavalla sekä lisäämällä työmarkkinoiden vastuuta tarkastaa missä olosuhteissa he joutuvat työskentelemään. Maahanmuuttajien alttius ihmiskaupalle vähenee mitä paremmin he pystyvät integroitumaan ja luomaan itselleen sosiaalisia verkostoja.

Ihmiskauppa on perinteisesti katsottu olevan osa organisoitua rikollisuutta. Biaudet korosti, että ihmiskaupan takana voivat olla myös yksittäiset henkilöt. Ei ole tavatonta, että tekijät, jotka itsekin ovat useasti ulkomaalaisia, ovat samaa etnistä taustaa olevia ja sukua uhreille. Läheinen suhde mahdollistaa uhrien pysyvän tekijöiden pihdeissään.

Biaudet totesi ihmiskaupan tunnistamisen suurimpana ongelmana olevan epäuskon kulttuuri; ei uskota, että ihmiskauppaa esiintyy meillä. Omat asenteet ja tietämättömyys ovat suurimmat haasteemme, Biaudet totesi.

Koska ihmiskauppa muuttaa helposti muotoaan ja uusia menetelmiä otetaan käyttöön, tulisi huomio kiinnittää ihmiskauppaindikaattoreihin, eikä niinkään määrättyihin määritelmiin. 
Työ- ja oleskelulupaprosessissa tulisi ottaa huomioon, ettei luppia myönnettäisi siten, että luvat pakottaisivat henkilön jäämään edes lievään hyväksikäyttötilanteeseen, totesi Biaudet. Lisäksi Biaudet korosti, että on erittäin tärkeää, että maahanmuuttajiin kohdistuneet vakavat rikokset priorisoidaan muiden lievempien maahantuloon liittyvien rikkomusten kustannuksella.

Biaudet korosti, että yhteiskunnalla on velvollisuus suojata uhreja ja ryhtyä tehokkaisiin toimenpiteisiin uhriutumisen estämiseksi. Hänen mukaan tämä edellyttää muun muassa sitä, että

\begin{abstract}
"työlupia ei enää myönnettäisi määrätyn työnantajan työhön ja että alihankkijoiden rekrytoimilla työntekijöillä tulisi olla nimet ja osoitteet sekä työterveyshuoltoon että luottamushenkilöihin. Alihankkijoita käyttävillä työnantajilla tulisi olla suurempi vastuu kuin tällä hetkellä valvoakseen, että perustavalaatuisia työoikeuksia noudatetaan kaikessa toiminnassa. Kouluilla ei enää voi olla siivoojia ilman nimeä! Työsuojelun tulisi tehostaa yhteistyötä poliisin ja työterveyshuollon kanssa. Terveyshuollon pitäisi nähdä vastuunsa ihmiskaupan uhrien tunnistamisessa ja uhrien avun tarjoamisessa."
\end{abstract}

Biaudet korosti näin ollen kaikkien vastuuta tilanteissa, joissa on merkkejä vakavasta ihmisten hyväksikäytöstä työelämässä. Ei saa myöskään unohtaa, että ihmiskauppatapauksen paljastumisesta seuraa pitkään kestävä oikeusprosessi. Biaudet muistutti uhrin tarpeesta saada myös apua tämän päästyä irti ihmiskauppiaan kontrollista. Apu ei saa olla sidoksissa siihen, onko esitutkinta aloitettu. On tärkeää turvata uhrin oikeuksia myös oikeusprosessin jälkeen sekä varmistaa ettei uhri joudu uudestaan ihmiskauppiaiden käsiin. 



\section{Istunto I Työvoiman rekrytointi Pohjoismaihin}

Istunnon tavoitteena oli paneutua muun muassa seuraaviin kysymyksiin:

- Kuinka työvoimaa rekrytoidaan? Miltä rekrytointiprosessit vaikuttavat?

- Kuka huolehtii rekrytoinnista; yksityiset ihmiset, rekrytointiyritykset, ulkomaalaiset vai kotimaiset?

- Mistä työvoima rekrytoidaan, kotimaasta vai kohdemaasta?

- Millaisia toimia Pohjoismaissa tarvitaan tulevaisuudessa, jotta rekrytoitu työvoima ei joutuisi ihmiskaupan uhriksi?

\section{Puheenjohtaja Anna Ekstedt, Vanhempi erityisasiantuntija,} Itämeri-neuvoston (CBSS) ihmiskaupanvastainen työryhmä

Avauspuheenvuorossaan vanhempi erityisasiantuntija Anna Ekstedt esitteli CBSS:n raportin Action Against Trafficking for Labour Exploitation, joka on kartoitus niistä toimijoista, joilla on tai pitäisi olla rooli työperäisen ihmiskaupan torjumisessa CBSS:n jäsenmaissa. Raportin mukaan suurin osa CBSS:n jäsenmaista ei ole päässyt pitkälle työperäisen ihmiskaupan ehkäisemisessä. Niin ikään lainvalvontaviranomaisilta, oikeuslaitokselta ja sosiaaliviranomaisilta puuttuu tietoa ja välineitä niin resurssien kuin mandaatinkin puolesta ongelman tehokkaaseen ehkäisemiseen. Kartoituksen mukaan positiivista kehitystä on tapahtunut ihmiskaupan torjunnan operatiivisella ja poliittisella tasolla - tietoisuus ihmiskaupasta on alkanut herätä. 


\subsection{Sairaanhoitajien rekrytointi Ullevålin sairaalaan Oslossa}

\section{Poliisitarkastaja Bjørn Vandvik, Ulkomaalais-ja hallintoyksikkö, Oslon poliisipiiri, Norja}

Poliisitarkastaja Bjørn Vandvik kertoi tuoreesta tapauksesta, joka tapahtui Norjassa keväällä 2012. Tapauksessa oli kyse filippiiniläisistä sairaanhoitajista, jotka rekrytoitiin Ullevålin sairaalaan Osloon rekrytointiyrityksen kautta. Rekrytointiyritys huolehti hoitajien asunnosta, kielikoulutuksesta ja ruoasta. Kulut vähennettiin suoraan sairaanhoitajien palkasta. Sairaanhoitajat eivät saaneet käydä ulkona ja heitä kiellettiin seurustelemasta muiden kuin toisten filippiiniläisten kanssa. Sairaanhoitajat pakotettiin allekirjoittamaan rekrytointiyrityksen kanssa sopimus, jossa he sitoutuivat jopa 300.000 NOK lainaan, joka oli määrätty rekrytointikulujen kattamiseksi. Rekrytointiyritystä syytettiin ihmiskaupasta, ja lisäksi Ullevålin sairaala syytti rekrytointiyritystä petoksesta.

Vandvik korosti, että ihmiskauppaa esiintyy yleensä ammateissa, joihin ei liity muodollisia pätevyysvaatimuksia; esimerkiksi rakennus-, siivous-, kuljetus-, kauppa- ja ravintola-alalla sekä myös au-pairien keskuudessa. Merkittävää mainitussa sairaalatapauksessa on, että kyseessä on ammatti, jota yleisesti kunnioitetaan, jossa on hyvä palkka, joka vaatii norjan kielen taitoa ja ammatillisen koulutuksen. Tapauksessa uhrit olivat koulutettuja sairaanhoitajia.

\section{Suositukset}

- Pakkotyö tulee ymmärtää osana siirtolaisuuteen liittyvää rikollisuutta.

- Ihmiskaupan indikaattoreista tulee olla tietoinen.

- Viranomaisten toteuttama seuranta ja valvonta työpaikoilla, jotta kiinnijäämisen riski kasvaa.

- Palvelun loppukäyttäjän vastuuta pitää kasvattaa, ja rekrytointiyritysten valvontaa on lisättävä. 


\subsection{Ulkomaalaiset marjanpoimijat Suomessa}

\section{Tutkija Pekka Rantanen, Tampereen yliopisto, Tampere, Suomi}

Tutkija Pekka Rantanen Tampereen yliopistosta esitteli thaimaalaisia marjanpoimijoita koskevaa tutkimushanketta.

Marjanpoimijat rekrytoitiin Thaimaasta nk. koordinaattorien kautta. Marjanpoimijoiden valinta tehtiin pitkälti edellisten vuosien tulosten ja marjanpoimijoiden sukupuolen perusteella. Miehet olivat valinnassa etusijalla, sillä he kestävät paremmin fyysistä työtä. Koska sukupuoleen liittyviltä ongelmilta haluttiin välttyä leirissä, pyrittiin työhön valitsemaan miehiä ja naisia, joilla oli leirissä miespuolisia sukulaisia tai jotka olivat parisuhteessa. Koordinaattoreiden täytyi olla thaimaalaisten viranomaisten hyväksymiä. Niiden toimintaan ei siis sovelleta virallisia rekrytointiyrityksiä koskevaa lainsäädäntöä. Koordinaattori matkustaa marjanpoimijoiden kanssa Suomeen, ja hän voi toimia esimerkiksi leirinjohtajana tai marjanpoimintapaikkojen kartoittajana.

Marjanpoimijoiden taloudellinen tilanne voi vaihdella paljon riippuen siitä, omistavatko he maata kotimaassaan vai eivät. Jotkut voivat jopa olla varakkaita thaimaalaisten normien mukaan. Tarvittaessa koordinaattori voi antaa poimijoille lainaa, mikä usein johtaa siihen, että marjanpoimijoiden pitää vuorostaan maksaa takaisin poimimalla marjoja. Tulkinta siitä, onko kysymys ihmiskaupasta tai työvoiman hyväksikäytöstä, riippuu ensisijaisesti siitä, kuinka marjanpoimijat ovat rahoittaneet marjanpoimintamatkansa. Riippuvuusasetelma ihmiskaupassa muodostuu rekrytointi- ja matkakuluista, sekä lainanottamisesta tähän tarkoitukseen.

Haaste marjanpoimijoiden tunnistamisessa ihmiskaupan uhreiksi liittyy siihen, että he työskentelevät muusta yhteiskunnasta erillään. Koska marjanpoimijat eivät ole työsuhteessa, eivät viranomaiset tarkkaile heitä Suomessa. Ruotsissa marjanpoiminta tapahtuu työsuhteessa, mikä suojelee uhria enemmän. Tämä ero tulee esille lähinnä huonoina satokausina. Suomessa edellytetään miniminettotulotasoa, mikä lähentää Suomen tilannetta Ruotsin malliin. Suomessa marjanpoimintaa ei tästä huolimatta pidetä työsuhteena. 


\section{Suositukset}

- Marjanpoimijoiden riippuvuutta rekrytoinnin rahoituksesta pitäisi vähentää. Todellisia tuloja ja menoja pitäisi voida seurata. Rekrytoinnin aiheuttamat kulut eivät saisi nousta liian suuriksi. Riski pitäisi jakaa tasaisemmin marjanpoimijoiden, rekrytoijien ja marjayritysten kesken.

- Viranomaisten pitäisi valvoa marjanpoimintamatkojen rahoittamista tarkemmin.

- Marjanpoimijoita pitäisi jo kotimaassaan tiedottaa paremmin marjanpoiminnan ehdoista.

- Parempi yhteistyö Suomen ja Thaimaan välillä. Suomen Bangkokin suurlähetystön ja Thaimaan työministeriön välinen kontakti on tärkeä ihmiskaupan ehkäisemiseksi.

- Tiedonjakaminen ja yhteiset pelisäännöt ovat edellytys sille, että uhrin tunnistaminen on mahdollista.

\subsection{Au-paireihin ja siivousalaan kohdistuva ihmiskauppa - riskit, rekrytointi ja välittäjät}

\section{Antropologi, fil.toht. stipendiaatti Trine Mygind Korsby, Antropologian laitos, Kööpenhaminan yliopisto, Kööpenhamina, Tanska}

Tutkija Trine Mygind Korsby esitteli kahta tutkimusta, jotka hän on tehnyt Ihmiskaupan vastaisessa keskuksessa (Centret mod Menneskhandel) Tanskassa. Tutkimukset käsittelivät au-paireihin ja siivousalaan kohdistuvaa ihmiskauppaa. Tutkimukset eivät kohdistuneet tapauksiin, joissa ihmiskauppaa oli havaittu, vaan tapauksiin, joissa oli ilmennyt ihmiskaupan indikaattoreita. Tutkimus nosti esiin muutamia kriittisiä tekijöitä: velkaantuminen, pieni palkka, pitkät työajat, ei vapaapäiviä, tietämättömyys omista oikeuksista, samoin kuin yleinen halvan ja joustavan työvoiman tarve näillä sektoreilla. Tutkimuksessa voitiin todeta, että rekrytointiyrityksillä oli valtaa auttaa uhreja tai vahingoittaa heitä. Monet työnantajat auttavat maahanmuuttajia, mutta monet myös käyttävät heitä hyväkseen. Monet maahanmuuttajat olivat tyytyväisiä tilanteeseensa ja toivoivat voivansa pitää työpaikkansa. Heidän suurin pelkonsa oli työpaikan menettäminen. Jotkut maahanmuuttajat halusivat työskennellä enemmän ja asua huonommissa olosuhteissa säästääkseen rahaa. Tämä herätti kysymyksen, oliko raja työ- 
voiman hyväksikäytöstä ylittynyt. Työnantajia tai rekrytoijia ei välttämättä nähty "pahiksina", vaan heitä pidettiin usein auttavina käsinä monimutkaisissa maahanmuuttoprosesseissa. Tutkimus pystyi myös todentamaan, että mitä enemmän maahanmuuttoon liittyviä rajoituksia oli, sitä enemmän maahanmuuttaja tarvitsi ulkopuolista apua maahanmuuton onnistumiseksi.

\section{Suositukset}

- Yhteistyötä keskeisten toimijoiden välillä (ammattiyhdistykset, yksityinen sektori, kuluttajat).

- Huomio ihmiskaupasta käytävän keskustelun vivahteisiin. Se ei ole aina selvää, mustavalkoista, oikeaa tai väärää.

- Ihmiskauppa ja työvoiman hyväksikäyttäminen pitäisi nähdä sellaisessa asianyhteydessä, missä lievää työvoiman hyväksikäyttöä ilmenee ja erikseen sellaisessa, missä hyväksikäyttö on vakavaa. Kaikki ei ole ihmiskauppaa, mutta kaikkien pitäisi ymmärtää, että on olemassa riski, että tilanne voi kehittyä ihmiskaupaksi myöhemmin.

\subsection{Kommenttipuheenvuoro}

\section{II puheenjohtaja Kyösti Suokas, Rakennusliitto, Suomi}

Toinen puheenjohtaja Kyösti Suokas totesi puheenvuorossaan, että ongelmia ilmaantuu kun on köyhiä ihmisiä ja liian vähän työpaikkoja. Suokas on työssään nähnyt eroja siinä, kuinka eurooppalaisia ja kolmansista maista saapuvia henkilöitä kohdellaan. Eurooppalaiset saavat usein sen, mitä heille on luvattu, kun taas kolmansista maista saapuvia huijataan ja hyväksikäytetään helpommin. Suokas painotti, että ihmiskaupan vastaisen työn ehkäisemiseksi tarvitaan muutakin kuin vain viranomaisten pistotarkastuksia ja kontrollia. Tarvitaan laajoja muutoksia viranomaisten toimintatapoihin ja järjestelmään, jotta harmaaseen talouteen päästään käsiksi. Suokas korosti myös, ettei vain palkkojen alentamalla luoda lisää työpaikkoja. 


\section{Suositukset}

- Tulee esittää vaatimus, että kaikilla (rakennusalan) työntekijöillä on henkilökortti, josta heidän veronumeronsa käy ilmi.

- Useiden osapuolten tulee tehdä yhteistyötä jo työvoiman rekrytointivaiheessa (teollisuus, ammattiyhdistykset, viranomaiset).

- Tieto työperäisestä ihmiskaupasta on tällä hetkellä riittämätöntä, ongelma täytyy priorisoida ja tietoa on lisättävä. Tämä vaatii poliittista tahtoa.

\subsection{Istunnon suositukset}

- Täytyykö pakon tunnusmerkistön olla niin vahva Palermon sopimuksessa?

- Koko harmaata taloutta ehkäisevää järjestelmää on kehitettävä.

- Yksittäisten tarkastusten määrää työpaikoilla on kasvatettava

- Pakko käyttää henkilökorttia rakennustyömailla.

- Uhrin auttaminen on tärkeää, auttamisen muodot räätälöitävä naisille ja miehille sopiviksi. 


\section{Istunto II}

\section{Ihmiskaupan ja työvoiman hyväksikäyttö Pohjoismaissa}

Istunnon tavoitteena oli keksittyä muun muassa seuraaviin kysymyksiin:

- Minkälaisia syitä hyväksikäytön takana on

- Miksi työvoimaa hyväksikäytetään? Kuka joutuu hyväksikäytetyksi?

- Mitkä ovat hväksikäytön muodot? Millaisissa olosuhteissa uhrit joutuvat elämään?

- Mikä tekee hyväksikäytöstä ihmiskauppaa?

- Milloin on kyse työvoiman hyväksikäytöstä, milloin ihmiskaupasta?

- Millaisilla toimenpiteillä työvoiman hyväksikäyttö estetään Pohjoismaissa?

\section{Puheenjohtaja Maria Stenberg, kansanedustaja, Ruotsi, kansalais- ja kuluttajavaliokunta, jäsen, Pohjoismaiden neuvosto}

Kansanedustaja Maria Stenberg aloitti toisen istunnon nostamalla esiin eri toimijoiden yhteistyön tärkeyden. Stenberg korosti viranomaisyhteistyön lisäksi myös työmarkkinaosapuolten, YK:n kaltaisten kansainvälisten järjestöjen, Euroopan neuvoston, Euroopan Unionin ja kansainvälisen työjärjestö ILO:n yhteistyön merkitystä. Stenberg korosti, että ihmiskaupan monimutkaisen luonteen vuoksi sen torjumisen keinot tulevat olla laajat ja kattavat. 
Kuva 2. Osallistujat valmistautuvat kuuntelemaan miten ihmiskauppa ja työntekijöiden hyväksikäyttö liittyvät toisiinsa Pohjoismaissa

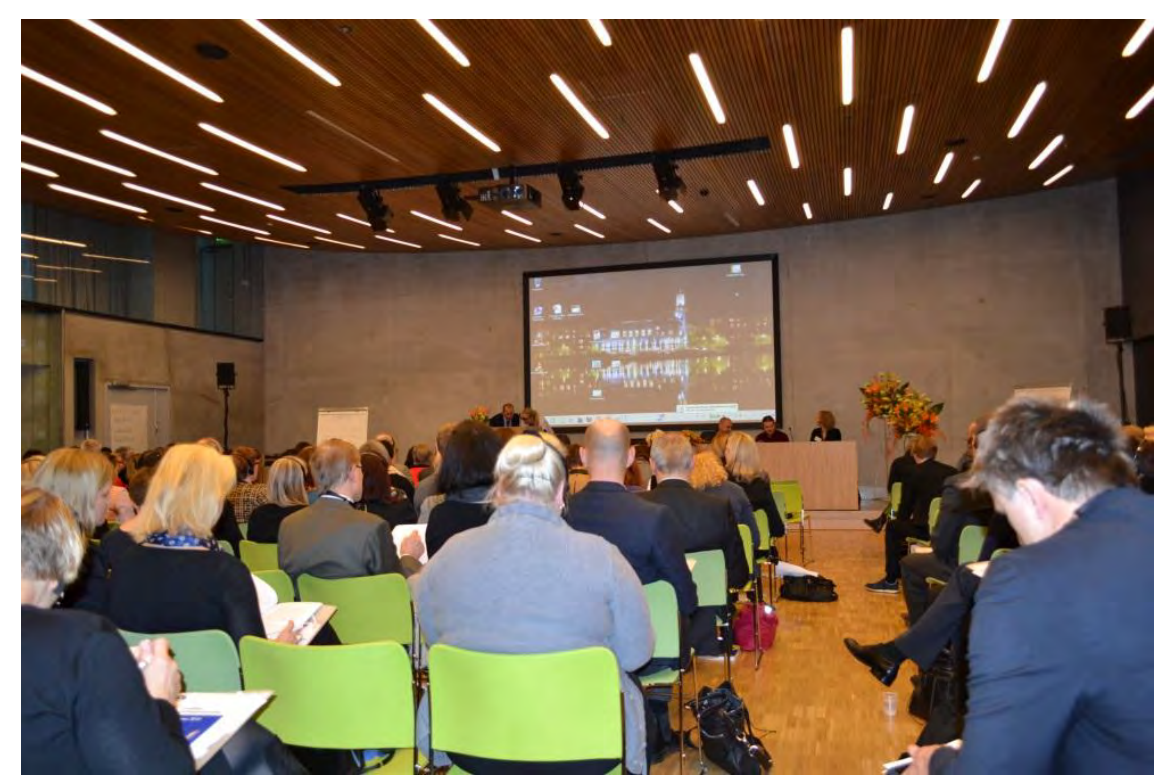

Valokuvaaja: Matti Keränen.

\subsection{Ihmiskauppiaat - veroviraston toimet ihmiskauppaa vastaan}

\section{Projektijohtaja John Vorbeck Petersen, Talousrikokset, Verovirasto, Tanska}

Projektijohtaja John Vorbeck Petersen esitteli tanskalaisten veroviranomaisten projektia "Ihmiskauppiaat". Projekti kokoaa yhteen veroviranomaiset, poliisin, ihmiskaupanvastaiset toimijat, työsuojelun ja tarvittaessa muita osapuolia, kuten ammattiliittoja. Veroviranomaisten roolina on ollut avustaa muun muassa taloustiedoissa. Projektin aikana Tanskan verovirasto on kouluttanut yhteistyötahoja ihmiskaupasta, jakanut informaatiomateriaalia, kehittänyt uusia toimintamalleja, kuten haastattelurunkoa ja solminut yhteistyösopimuksia tärkeiden kumppaneiden kanssa.

Petersen korosti puheenvuorossaan, että perussyy työvoiman hyväksikäytölle on raha. Esimerkiksi veronkierto on suhteellisen helppoa, mitä ihmiskauppiaat myös hyväksikäyttävät. Uhrit tulevat huonoista olosuhteista ja heillä on huonoja kokemuksia viranomaisista, minkä vuoksi uhrit eivät kerro hyväksikäytöstään. 


\section{Suositukset}

- Viranomaisyhteistyö kansallisesti, pohjoismaissa ja kansainvälisesti.

- Näkyvä kampanjointi. Kokemus on osoittanut, että lisätty tietoisuus ihmiskaupasta ja sen uhreista lisää myös halua torjua tätä ilmiötä.

- On perustettava kansallisia toimintaryhmiä.

- Pohjoismaisen ryhmän perustaminen kokemusten vaihtamiseksi.

\subsection{Ammattiyhdistysten toimet työmarkkinoilla tapahtuvaa ihmiskauppaa vastaan Pohjoismaissa}

\section{Maahanmuuttopoliittinen asiantuntija, tutkija Thord Ingesson, LO, Ruotsi}

Tutkija Thord Ingesson huomautti puheenvuoronsa aluksi, että EU:n laajentuminen on merkittävästi vaikuttanut ihmiskauppaan Pohjoismaissa. Ingesson muistutti, että ihmiskauppa on ensisijaisesti poliisiasia, eikä ammattiliittojen ratkaistavissa. Ammattiliitot ovat mukana työssä ja työehtosopimukset koskevat myös ihmiskaupan uhreja. Ingesson nosti esiin aktiiviset toimet: Tarvitaan sääntöjen kehittämistä ja viranomaisyhteistyön tiivistämistä. Ingessonin mukaan esimerkiksi Ruotsin työlupajärjestelmä on ihmiskauppiaan unelma. Vuonna 2008 Ruotsi uudisti työperäisen maahanmuuton säännöksiä, mikä helpotti työvoiman rekrytoimista kolmansista maista. Uudistuksen myötä työvoiman tarveharkinta poistui työvoimatoimistoilta ja tarveharkinta siirtyi yrityksiin. Ingesson totesi, että Schengen-alueelle pääseminen on helppoa Ruotsin kautta, mikä on tehnyt Ruotsista kauttakulkumaan.

Ingesson korosti, että talousrikollisuus ja taloudelliset voitot ovat keskeisiä taustatekijöitä ihmiskaupassa. Ingesson korosti, että ihmiskauppiaat ovat ammattirikollisia, jotka toimivat rikollisverkostoissa. Tämän kaltaisen rikollisuuden torjumiseksi tulisi pyrkiä takavarikoimaan rikollisten rahat ja ryhtyä ankariin toimiin rikollisverkostoja vastaan uusien verkostojen syntymisen ehkäisemiseksi.

\section{Suositukset}

- Talousrikollisuuden torjutaan tarvitaan lisäpanostuksia.

- Ihmiskaupan torjumisen ulottaminen maiden rajojen yli. 
- Ihmiskauppiaat ovat usein ammattirikollisia. Tehokkainta on pyrkiä pääsemään käsiksi heidän rahoihin ja estää uusien rikollisverkostojen syntyminen.

- Vahvistaa tilaajavastuuta.

- Yhteistyö on välttämätöntä. Ihmiskauppa ei ole yksittäisen maan asia - ainoastaan kansallisilla toimilla ei voi taistella ihmiskauppa vastaan.

\subsection{Työvoiman hyväksikäyttö Suomessa työsuojelun näkökulmasta}

\section{Tarkastaja Kristiina Linna, Työsuojelun vastuualue, Lounais-Suomen aluehallintovirasto}

Kristiina Linna kertoi kokemuksistaan ulkomaisen työvoiman valvonnasta Lounais-Suomessa. Työvoiman hyväksikäytön syitä on hänen mukaan vaikea eritellä. Linnan mukaan hyväksikäytössä voi olla kyse hyväksikäytetyn tietämättömyydestä esimerkiksi lainsäädännöstä tai kulttuurieroista. Linna mainitsi, että Suomessa kovaa työtä on aina arvostettu ja esimerkiksi maataloudessa työnantajat odottavat, että työntekijät tekevät töitä ilman vapaapäiviä. Kaikissa Linnan kohtaamissa työntekijöiden hyväksikäyttötapauksissa työntekijällä on ollut oleskelulupa Suomeen. Linnan mukaan ilman oleskelulupaa tehtävä luvaton työ on harvinaista Suomessa. Linna huomautti, että viranomaisten toteama työntekijän hyväksikäyttö johtaa usein tilanteeseen, jossa hyväksikäytetylle ei myönnetä jatkuvaa oleskelulupaa. Näin työnantajan työehtojen ja lakien laiminlyönnit johtavat myös työntekijän karkottamiseen maasta.

Työsuojeluviranomaiset ilmoittavat maahanmuuttovirastolle sekä työ- ja elinkeinotoimistoille työluvasta, kunnan terveys- ja rakennustarkastajille ja myös veroviranomaisille kun tarkastuksia tehdään työpaikoilla. Jos tarkastaja epäilee ihmiskauppaa tai kiskonnantapaista työsyrjintää, tarkastaja ottaa yhteyttä poliisiin ja ihmiskaupan auttamisjärjestelmään.

Linna totesi, että tarkastajien kyky tunnistaa ihmiskauppaa parantuu kokemuksen karttuessa. Tarkastajat oppivat hoitamaan tapauksia paremmin esimerkiksi niin ettei tarkastus johda työntekijän rankaisuun työnantajan puolesta. Työnantajat ovat saattaneet luulla, että työpaikalle tehtävän tarkastuksen on pyytänyt työntekijä. Hyvä esimerkki toimivasta käytännöstä on työsuojelun ja poliisin yhteistyö. Poliisi ei kutsu työn- 
antajaa kuulusteluun ennen kuin hyväksikäytön uhri on otettu osaksi ihmiskaupan uhrien auttamisjärjestelmää.

Linna nosti esiin yleissitovien työehtosopimuksien merkityksen ihmiskaupan torjumisessa. Työnantajien, jotka eivät kuulu mihinkään ammattiliittoon on noudatettava yleistä työehtosopimusta palkkauksessaan.

\section{Suositukset}

- Työsuojelutarkastajat, poliisit, rajavartiolaitos ja viranomaiset on koulutettava paremmin tunnistamaan ihmiskauppaa.

- Asennemuutos. Suomessa ja Pohjoismaissa on ihmiskauppaa, sitä ei ole vain tunnistettu aikaisemmin. Ihmiskaupasta säilytettävä realistinen käsitys, eikä ihmiskauppaa pidä nähdä aina siellä, missä ulkomaista työvoimaa on.

- Säännölliset ja kattavat tarkastukset myös ongelmien ennaltaehkäisyyn. Tarkastusten aikana tarkastajien olisi tiedotettava työntekijöille työehtosopimuksista ja lainsäädännöstä, työntekijöiden oikeuksista ja työnantajan velvollisuuksista.

\subsection{Kommenttipuheenvuoro}

\section{Johtaja Jari Kähkönen ihmiskaupan uhrien auttamisjärjestelmä, Joutsenon vastaanottokeskus, Suomi}

Jari Kähkönen kuvasi puheenvuorossaan ihmiskaupan uhrien määrien kasvua Suomessa. Auttamisjärjestelmässä on lähes 100 ihmiskaupan uhria, joista suurin osa on uhriutunut työelämässä.

\section{Suositukset}

- Miesten ja naisten avun ja palvelujen tarve poikkeavat toisistaan. Nykyisin tarvitaan avustusjärjestelmä ja palveluja, jotka ovat suunniteltu miesuhreille.

- Tietoa työntekijöiden oikeuksista tarjottava työntekijöiden kotimaassa. Tietoa tarjottava heidän äidinkielellään esimerkiksi oleskelulupaa haettaessa.

- Koulutusta ihmiskaupan uhrien parissa toimiville, esimerkiksi sosiaali- ja terveydenhuollon henkilökunnalle. 
- Keskitetympi ja tehokkaampi viranomaisselvitys ihmiskauppatauksista, esimerkiksi perustamalla erillisiä työryhmiä.

- Toimenpiteet, joille estetään uudelleenuhriutuminen.

\subsection{Keskustelu}

Toisen istunnon keskustelussa kiinnitettiin huomiota muun muassa tilaajan vastuuseen ulkomaisen työvoiman käytössä. Thord Ingesson nosti esiin, että esimerkiksi pääurakoitsijan tulisi kantaa vastuunsa ihmiskaupan torjumisessa. Pääurakoitsijalla on vastuu seurata, mitä aliurakoitsijoiden ketjun toisessa päässä tapahtuu. Tätä tulisi korostaa nykyistä enemmän.

Lisäksi painotettiin viranomaisten vastuuta ihmiskaupan tunnistamisessa. Usein ihmiskaupan uhri ei itse tiedä olevansa ihmiskaupan uhri. Tällaisissa tapauksissa on tärkeää muistaa, että viranomaisilla on vastuu tutkia, onko kyse ihmiskaupasta. Vastuuta ei voi jättää uhrille, sillä uhri ei itse kykene arvioimaan tilannettaan.

\subsection{Istunnon suositukset}

- Yhteistyön lisääminen viranomaisten ja kaikkien ihmiskaupan torjumisen parissa toimivien välillä.

- Tarvitaan keskustelua oleskelulupakäytännöistä.

- Talousrikollisuuden torjuntaan lisäsatsauksia.

- Kansalaisjärjestöjen roolia vahvistettava. 


\section{Istunto III Oikeudelliset prosessit}

Istunnon tavoitteena oli keskittyä muun muassa seuraaviin kysymyksiin:

- Millaisia ongelmia liittyy työperäistä ihmiskauppaa koskevaan oikeudenkäyntiprosessiin (esitutkinta, syyte, asian käsittely tuomioistuimessa) - konkreettisia esimerkkejä konkreettisista ongelmista?

- Kuinka nämä ongelmat on ratkaistu niissä tapauksissa, jotka on tuotu tuomioistuimeen - tai kuinka niitä ei ole ratkaistu?

- Kuinka hahmottaa työperäisen ihmiskaupan määritelmän ja rajanvedon muuhun samantyyppiseen rikollisuuteen?

- Mitä on tärkeää ottaa huomioon tulevaisuudessa, jotta työperäistä ihmiskauppaa tutkittaisiin, siitä nostettaisiin syytteitä ja annettaisiin tuomioita aiempaa enemmän?

Puheenjohtaja Natalia Ollus, erikoissuunnittelija, YK:n yhteydessä toimiva Euroopan kriminaalipolitiikan instituutti (HEUNI), Suomi

Erikoissuunnittelija Natalia Ollus painotti, ettei ihmiskauppaa tule nähdä rikoksena, joka tapahtuu tiettynä ajankohtana tietyllä tavalla, vaan pikemminkin hyväksikäytön prosessina. Toimintatavat, joita työntekijän kontrolloimiseksi käytetään, ovat erittäin hienovaraisia. 


\subsection{Norjalainen oikeustapaus - syyttäjän ja poliisin välinen yhteistyö}

\section{Tutkinnanjohtaja Jarle Bjørke, Bergenin poliisin organisoidun rikollisuuden analyysi- ja koordinointiyksikkö, Hordalandin poliisipiiri, Norja}

Tutkinnanjohtaja Jarle Bjørke aloitti puheenvuoronsa kehottamalla kaikkia välittämään ihmiskaupan uhreista. Ainoastaan jos otamme heidät tosissaan, he kertovat meille tarinansa. Bjørke nosti esille muutamia keskeisiä menestykseen johtaneita asioita, jotka ovat EXIT-ryhmässä, Hordalandin poliisipiirissä Bergenissä Norjassa, osoittautuneet tärkeiksi. Bjørke muun muassa vaati esitutkintaviranomaisten sitouttamista asiaan. Lisäksi täytyy olla ammattitaitoa ja kykyä haastaa vakiintuneet yleiset mielipiteet, oman ja työyhteisössä vallitsevan "kulttuurin" sekä perinteiset esitutkinnalliset toimintatavat. Hyvällä esitutkintaviranomaisella täytyy olla myös empatiaa ja kunnioitusta uhria kohtaan.

Bjørke painotti myös esitutkintaviranomaisen ja syyttäjien välisen yhteistyön merkitystä. Syyttäjän ja poliisin on tehtävä läheistä yhteistyötä tulosten saavuttamiseksi. EXIT-ryhmän kokemusten mukaan on ollut hyvä, että syyttäjän ja poliisin virastot sijaitsevat fyysisesti toisiaan lähellä. Bjørke huomautti, että ihmiskauppa on alue, jonka parissa kaikki juristit joko voivat tai haluavat työskennellä. Ihmiskaupan vastaisessa työssä kohdataan monia haasteita, joilta muussa poliisityössä voi välttyä; ihmiskauppa vaatii esimerkiksi enemmän luovuutta ja argumentointia. Uhrit tulevat köyhemmistä ja haavoittuvaisemmista olosuhteista kuin ihmiskaupan torjumisen parissa työskentelevät henkilöt. Bjørke huomautti, että uhrin hyvä hoito on hyvä sijoitus. Apujärjestelmän kautta tarjottava apu uhrille on ratkaisevan tärkeää poliisin tutkimustyölle ja sen eteenpäin viemiseksi tuomioistuimeen. Toimiva apujärjestelmä vähentää fyysistä ja psyykkistä stressiä, jota esitutkinta ja oikeudenkäynti aiheuttavat uhrille. Ihmiskaupan esitutkinnassa on tärkeää muistaa, että ihmiskauppa muuttaa jatkuvasti muotoaan. Esitutkintaviranomaisten täytyy siksi toimia nopeasti.

Oikeudenkäynnissä EXIT-ryhmä on käyttänyt asiantuntijatodistajia, jotka ovat paikallisia, kansallisia ja kansainvälisiä ihmiskaupan asiantuntijoita, jotka voivat kuvailla ihmiskauppaa ja antaa tuomioistuimelle faktoihin perustuvan kuvauksen ihmiskaupasta. Yhteistyö poliisin, syyttäjien ja asiantuntijatodistajien välillä on tärkeää hyvän tuomioistuinprosessin kannalta. 
Bjørke mainitsi halpatyövoiman hyväksikäytön yhdeksi syyksi ihmiskaupalle, sillä haavoittuvassa asemassa olevat ihmiset ovat helposti hyväksikäytettävissä. Bjørke nosti esille myös kustannuskysymykset; asian, joka usein nousee keskusteluun ihmiskauppaselvitysten yhteydessä. Bjørke korostikin, että jos me pohjoismaalaiset olemme riittävän rikkaita hyväksikäyttämään uhreja, olemme varmasti myös riittävän rikkaita auttamaan heitä. Ihmisarvoa ja ihmisoikeuksia kunnioittaen on ihmiskaupan torjuminen ja uhrin auttaminen rangaistusprosessissa on hyvä sijoitus, jonka ansiosta ongelma voidaan ratkaista paljon lyhyemmässä ajassa ja rahaa säästäen.

\section{Suositukset}

- Perustetaan ihmiskauppaan erikoistunut esitutkintaviranomainen.

- Läheinen yhteistyö syyttäjän ja poliisin välillä.

- Matala kynnys toiminnan ja strategioiden uudistamiselle.

- Asiantuntijatodistajien käyttäminen oikeudenkäynnissä.

- Ennaltaehkäisevä työ työpaikoilla, kouluissa ja yrityksissä.

- Sen haavoittuvan tilanteen dokumentointi, jossa uhri on tai josta hän tulee.

- Uhrin apujärjestelmän kehittäminen.

- Ihmisarvon ja ihmisoikeuksien kunnioittaminen uhrin kohtelussa.

- Yksinkertaisempia sääntöjä työperäiseen maahanmuuttoon.

- Minipalkan käyttöönottaminen.

- Parempi tiedottaminen työntekijöiden oikeuksista, erityisesti siirtotyöläisten kohdalla.

- Sen selventäminen, mikä on ja mikä ei ole halpatyövoiman hyväksikäyttöä.

- Työsuojelun valvonnan vahvistaminen.

- Uhrien aseman parempi seuranta.

- Lisää valvontaa ja toimintaa vastuuttomia työnantajia kohtaan.

- Työsuojeluviranomaisen ja poliisin täytyy tehdä enemmän etsivää työtä uhrien tunnistamiseksi.

- Poliisille raportoimisen kynnyksen madaltaminen.

- Eri yksiköiden välinen tiedon jakaminen ja dokumentointi. 
- Nopeammat esitutkinnat.

- Muista: "I will only tell my story if you care about it."

\subsection{Ihmiskauppa marjanpoimijoilla - marjanpoimijoiden rekrytointi Ruotsiin}

\section{Syyttäjä Christina Voigt, Kansainvälinen syyttäjävirasto, Tukholma, Ruotsi}

Syyttäjä Christina Voigt esitteli Ruotsissa vuosina 2010-2012 tapahtunutta marjanpoimijoihin liittyvää ihmiskauppatapausta. Tapaus käsitteli bulgarialaisia marjanpoimijoita, jotka rekrytoitiin Ruotsiin vuosina 2010-2011. Monet marjanpoimijat ottivat yhteyttä poliisiin, koska heidän esimiehensä olivat huijanneet heitä: palkkoja ei ollut maksettu tai työntekijöitä oli kohdeltu kaltoin. Kaikki marjanpoimijat kertoivat saman tarinan, toisistaan riippumatta. Ensimmäinen syyte ihmiskaupasta, jonka tarkoitus oli pakottaa kyseiset henkilöt marjanpoimintaan, nostettiin vuonna 2011. Oikeuden mielestä Voigt ei osoittanut, että esimiesten tarkoitus oli hyötyä marjanpoimijoiden pakkotyöstä. Sen sijaan kaksi esimiestä tuomittiin marjanpoimijoiden uhkailusta, kaltionkohtelusta ja passien takavarikoimisesta. Tapaus sai medialta paljon huomiota.

Seuraava tapaus koski 13 marjanpoimijaa, jotka olivat kahden vuoden aikana olleet Ruotsissa kolme ajanjaksoa heikoissa olosuhteissa ja kenellekään ei ollut maksettu palkkaa. Voigt esitti kysymyksen: Olivatko nämä marjanpoimijat yksinkertaisesti solmineet surkean sopimuksen vai olivatko he ihmiskaupan uhreja?

Ruotsalaisessa ihmiskauppaan liittyvässä lainsäädännössä on useita määritelmiä, joista kaikkien tulee täyttyä, jotta tapaus käsiteltäisiin ihmiskauppana oikeudessa. Mitä tulee lainsäädännön vaatimuksiin, Voigt'n mielestä kaikki momentit täyttyivät tässä tapauksessa. Marjanpoimijat olivat rekrytoitu ja kuljetettu Ruotsiin ja heille oli järjestetty majoitus, osittain harhaanjohtamalla, mutta jopa niin, että heidän esimiehensä sekä Bulgariassa että myöhemmin Ruotsissa olivat hyödyntäneet heidän ahdinkoaan. Koska tämä tilanne koski niin montaa marjanpoimijaa eri ajanjaksoina ja toisistaan riippumatta, Voigt'n mielestä esimiesten tarkoitus hyötyä muiden pakkotyöstä oli myös täyttynyt. Suurin ongelma huonon työsopimuksen ja ihmiskaupan erottamisessa on Voigt'n mielestä se, kuinka osoittaa, että ihmiskaupan harjoittajat ovat käyttäneet ns. vilpillisiä keinoja, mikä on yksi ruotsalaisessa lainsäädännössä esitetyistä vaatimuksista. Ns. vilpilliset keinot tarkoittavat sitä, 
että ihmiskaupan harjoittajat ovat joko uhanneet, kaltoin kohdelleet tai harhaanjohtaneet uhria, tai hyötyneet uhrin ahdingosta.

Vilpillisten keinojen käyttämisen todentaminen on jopa suurin haaste ihmiskauppatapauksissa. Marjanpoimijoiden tapauksessa yhtenä ongelmana oli, että marjanpoimijat olivat lukutaidottomia, heillä oli puutteita sanavarastossa, he eivät osanneet kelloa eivätkä he osanneet laskea. Tämä johti siihen, että heiltä oli vaikea saada todistajanlausuntoja, mikä toisaalta vahvisti sitä, että heitä oli harhautettu. Voigt totesi, ettei käräjäoikeuden mielestä hän saanut osoitettua, että marjanpoimijoita oli johdettu harhaan. Sen sijaan käräjäoikeus tulkitsi, että esimiehet olivat hyväksikäyttäneet marjanpoimijoiden ahdinkoa ja antoi siksi tuomion ihmiskaupasta. Tuomiosta on valitettu, ja sitä ei ole vielä käsitelty hovioikeudessa Ruotsissa.

Voigt'n johtopäätös on, että on periaatteessa mahdotonta osoittaa, että jotakuta olisi harhautettu kun puhutaan laillisesta työstä - kyseessä on tällöin vain "huono sopimus". Mutta jos tarkastellaan kuka tai mikä kohderyhmä tekee huonoja sopimuksia, nähdään, että nämä ovat ainoastaan köyhiä ihmisiä, jotka on velkaannutettu, joilta puuttuu tietoa ympäröivästä maailmasta, joilla ei ole kielitaitoa, joilta on otettu pois matkustusasiakirjat ja jotka ovat varattomia. He ovat yksinkertaisesti alttiita tilanteille, jossa heitä voi hyväksikäyttää pakkotyön muodossa.

Voigt päätti puheenvuoronsa toiveeseen, että ihmiset Ruotsissa olisivat saaneet työkaluja siihen, kuinka tunnistaa ihmiskauppa suhteessa pakkotyöhön. Eri tahojen, kuten poliisin, sosiaalitoimen virastojen, syyttäjien ja tuomareiden on tärkeää oppia tunnistamaan ongelma.

\section{Suositukset}

- Opitaan tunnistamaan ihmiskauppa.

- Ollaan herkkiä sille, mitä uhrit kertovat. Jos he kertovat saman tarinan, voi niistä muodostua ihmiskaupan malli.

- Yhteistyö Pohjoismaissa tiedon jakamiseksi ihmiskaupan parissa työskentelevien syyttäjien kesken.

- Täytyy uskaltaa puuttua ongelmaan, eikä antaa periksi vaikka prosessi onkin vaikea ja raskas. 


\subsection{Työperäinen ihmiskauppa - esitutkinnan ja prosessin haasteet syyttäjän näkökulmasta}

\section{Johtava kihlakunnansyyttäjä Peter Levlin, Pohjanmaan syyttäjänlaitos, Suomi}

Johtava kihlakunnansyyttäjä Peter Levlin kertoi kokemuksistaan ihmiskaupan parissa Pohjanmaan syyttäjänlaitoksessa. Tällä hetkellä vireillä on viisi tapausta, joissa syytetään ihmiskaupasta tai vaihtoehtoisesti kiskonnankaltaisesta syrjinnästä työelämässä - tai karkeasti sanoen kiskonnasta. Tämä on suhteellisen monta tapausta kun verrataan tilanteeseen muualla Suomessa.

Levlin sanoi, että vireillä olevat tapaukset olivat tulleet viranomaisten tietoisuuteen mahdollisesti siten, että yksi uhreista oli joutunut väkivallan kohteeksi ja etsinyt suojaa viranomaisilta. Kaikissa paitsi yhdessä tapauksessa tapaukset olivat tulleet tietoon säännöllisten tarkastusten kautta, ja siksi Levlin painotti tarvetta kehittää valvontaa ja tarkastuksia työpaikoilla.

Levlin sanoi, että poliisi oli vuoden aikana selvästi kehittänyt taitojaan ja prosessejaan ihmiskaupan tunnistamiseksi ja tutkimiseksi. Levlinin mielestä esitutkinnan alkuvaihe on kriittinen vaihe uhrin ja viranomaisen välisen luottamuksen syntymisen kannalta. Luottamus on edellytys onnistuneelle esitutkinnalle, sillä monilla uhreilla ei ole positiivisia kokemuksia yhteistyöstä viranomaisten kanssa omassa kotimaassaan.

Levlin painotti, että vaikka uhrin ja viranomaisen välisen luottamuksen rakentaminen ja yhteyden rikkominen rikoksentekijään onnistuisikin, on rikoksentekijällä silti tapa lähestyä uhria. Rikoksentekijä voi esimerkiksi uhrin kotimaassa olevien yhteistyökumppaneiden kautta kohdistaa paineita uhrin sukulaisia kohtaan. Näissä tapauksissa viranomaiset voivat tietenkin tutkia asiaa ja jopa nostaa syytteen uhrin pelottelusta. Levlin vaati parempaa yhteistyötä Suomen ja niiden maiden viranomaisten välillä, joista työntekijöitä rekrytoidaan.

\section{Suositukset}

- Viranomaisvalvonnan ja työturvallisuustarkastusten kehittäminen.

- Tärkeää rakentaa luottamus uhrin ja viranomaisen välillä alusta alkaen.

- Tärkeää eristää rikoksentekijä ja uhrit heti toisistaan ihmiskaupan auttamisjärjestelmän avulla tai rikoksentekijä pidättämällä. 
- Parempi yhteistyösopimus eri maiden oikeusavussa.

- Simultaanitulkkauksen käyttäminen oikeudenkäynnissä käsittelyajan lyhentämiseksi.

\subsection{Kommenttipuheenvuoro}

\section{Komisario Sigríður Björk Guðjónsdóttir, Suðurnesin poliisipiiri, Islanti}

Komisario Sigríður Björk Guðjónsdóttir nosti kommenttipuheenvuorossaan esiin uhrin luottamuksen viranomaisiin keskeiseksi asiaksi. On tärkeää turvata todistajien suojelu, jotta esitutkinta voi olla menestyksekäs. Guðjónsdóttir painotti myös, että on tärkeää seurata rikollisen toiminnan rahaliikennettä, ihmiskaupan tutkimisen ja torjumisen välineenä. Pohjoismainen yhteistyö on myös hyvä tapa torjua ihmiskauppaa. On tärkeää saada poliittista tukea, jotta voi aktiivisesti ehkäistä ihmiskauppaa Pohjoismaissa.

\section{Suositukset}

- Yhteistyö eri viranomaisten välillä, niin kansallisesti kuin kansainvälisestikin.

- Huomio rikollisen toiminnan rahaliikenteeseen - "follow the money".

- Ihmiskaupan parissa toimivien henkilöiden kouluttaminen.

- Fokus uhrin auttamiseen.

\subsection{Keskustelu}

Keskustelun aikana heräsi kysymyksiä muun muassa liittyen asiantuntijatodistajiin, joita käytetään Norjassa. Koska uhrit ovat joskus tietoisia siitä, että he tulevat työskentelemään huonoilla työehdoilla, voidaan jopa nähdä, että he olisivat antaneet suostumuksensa siihen. Niinpä pakkotyön olemassaolo kyseenalaistettiin keskustelussa. Vastauksena tähän todettiin, että uhrin suostumus on merkityksetön eikä se poista vastuuta niiden asiattomien keinojen käytöstä, joilla uhri on saatu suostumaan työhön. Tekijät ovat useimmissa tapauksissa ulkomaalaisia, jotka ovat hyväksikäyttäneet maanmiehiään. Ulkomaalaista työvoimaa rekrytoidaan, koska on helpompi hyväksikäyttää henkilöitä, jotka eivät 
tunne maan työehtoihin liittyvää lainsäädäntöä ja asetuksia. Rekrytointiin taas tarvitaan sellaisia kontakteja, joita ulkomaalaisilla on.

\subsection{Istunnon suositukset}

- Hyödynnä asiantuntijatodistajia oikeudenkäynnissä valaisemaan ihmiskaupan kokonaistilannetta.

- Aja asiaa aktiivisesti eteenpäin, kunnes onnistut siinä. Tiedot ja tietoisuus kasvaa ajan myötä.

- Vahva yhteistyö poliisin, syyttäjän ja työsuojelun välillä.

- Ihmiskaupparikostutkintaan erikoistuneita poliiseja.

- Yhteistyö oikeusavussa. 


\section{Istunto IV Noudattavatko Pohjoismaat omia oppejaan?}

Istunnon tavoitteena oli keskittyä muun muassa seuraaviin kysymyksiin:

- Kenestä tulee ihmiskaupan uhri?

- Kuinka uhrit itse näkevät tilanteensa?

- Mitä uhrit tarvitsevat, millaista apua?

- Millaista apua uhreille tarjotaan tällä hetkellä?

- Noudattavatko Pohjoismaat omia oppejaan?

- Mitä Pohjoismaat voivat tehdä työperäisen ihmiskaupan ehkäisemiseksi? Kuinka uhrien oikeuksia suojellaan?

\section{Puheenjohtaja Birgitte Ellefsen, korkeakoululehtori ja tohtoristipendiaatti, Poliisikorkeakoulu, Norja}

Korkeakoululehtori ja tutkija Birgitte Ellefsen totesi, että Pohjoismaat ovat kansainvälisesti korostaneet sen merkitystä, että uhrien oikeus apuun ja suojaan turvataan. Tästä huolimatta Ellefsen totesi, että kansalaisjärjestöjen tutkimukset ja raportit osoittavat, että Pohjoismaissa miespuolisille ihmiskaupan uhreille ei tarjota yhtä paljon apua kuin naisuhreille. On ryhdyttävä toimenpiteisiin niiden uhrien hyväksikäytön tunnistamiseksi ja suojelemiseksi, joita käytetään hyväksi kerjäämisessä, huumekaupassa, varkauksissa ja muussa rikollisessa toiminnassa. Lisäksi Ellefsen painotti, että ihmiskauppaa ei voida nähdä ainoastaan halpatyövoiman hyväksikäyttönä tai työlainsäädännön rikkomisena, vaan kyse on ihmisoikeuksien rikkomisesta. Tällä on ratkaiseva merkitys, jotta uhrien oikeus apuun ja suojaan toteutuisi. 


\subsection{Unelma koulutuksesta ja työstä}

\section{Johtaja Sirle Blumberg, Living for Tomorrow, Viro}

Johtaja Sirle Blumberg antoi selvityksen ihmiskaupan vastaisen työn kehityksestä, joka on tapahtunut viime vuosina Virossa. Esimerkiksi ihmiskauppa otettiin Viron lainsäädäntöön omana rangaistussäännöksenään vuonna 2012, mitä pidetään suurena edistysaskeleena Virossa. Blumberg kuvasi myös Living for Tomorrow -järjestön toimialaa. Järjestö työskentelee ihmiskaupan uhriksi joutuneiden henkilöiden auttamiseksi Virossa ja ulkomailla. Järjestöön tulee vuosittain noin 600 puhelinsoittoa. $70 \%$ puheluista koskee työvoiman hyväksikäyttöä Virossa ja loput ulkomailla tapahtuvaa hyväksikäyttöä. Uhrit ovat 30-55-vuotiaita naisia ja miehiä, joilla on perus- tai korkeakoulutus ja joilla on lainaa tai velkaa. Virolaiset matkustavat etsimään töitä etenkin Suomeen, Saksaan, Ruotsiin, Norjaan ja Venäjälle. Blumbergin mukaan yksityisten työnvälitystoimistojen kanssa on ollut ongelmia, sillä ne ovat vaatineet laittomia maksuja työvoimapalveluista. Ongelmia on myös niiden työnantajien kanssa, jotka eivät kuulu työehtosopimusten piiriin.

\section{Suositukset}

- Yksityisten työnvälitystoimistojen tarkempi valvonta.

- Työehtosopimuksen tulisi koskea kaikkia työnantajia.

\subsection{Kuka tulee työskentelemään Ruotsiin?}

\section{Yksikönjohtaja Arto Moksunen, Crossroads, Ruotsi}

Yksikönjohtaja Arto Moksunen esitteli Crossroadsin toimialaa Ruotsissa. Crossroads on EU:n rahoittama yhteistyöprojekti, jonka tarkoitus on ehkäistä syrjäytymistä ja köyhyyttä. Crossroads tarjoaa tietoa yhteiskunnasta, järjestää erilaisia kursseja (kieli, IT, työnetsiminen, ruoanlaitto) ja tarjoaa neuvoa ja oikeusapua. Crossroads ei kuitenkaan tarjoa työtä tai asuntoa. Ihmiset, jotka hakeutuvat Crossroadsiin, toivovat löytävänsä työtä, saavansa tietoa yhteiskunnasta omalla kielellään, solmivansa henkilökohtaisia kontakteja henkilökunnan kanssa, osallistuvansa koulutukseen ja onnistuvansa hankkimaan asunnon. Heidän ajatuksensa Pohjoismaista on, että siellä on töitä ja asuntoja, yhteiskunta toimii ja 
vastaanotto on hyvä. Ensimmäinen syy tulla Pohjoismaihin on, ettei kyseisillä henkilöillä ole mahdollisuutta saada työtä kotimaastaan.

\section{Suositukset}

- Tilastot on hyvä tapa kerätä perustietoja Pohjoismaihin tulevista henkilöistä.

- Tarjotaan yhteiskuntatietoutta jokaisessa maassa siirtotyöläisille.

- Kehitetään yhteyksiä lähtömaihin.

- Yhteistyötä yli rajojen.

- Kehitetään järjestelmällistä kotouttamista.

\subsection{Uhrien harkinta-ajat - kokemuksia seitsemästä maasta}

\section{Tutkija Anette Brunovskis, Työelämän- ja hyvinvoinnin tutkimuslaitos (FaFo), Norja}

Tutkija Anette Brunovskis esitteli tutkimustaan ihmiskaupan uhrien harkinta-ajoista. Harkinta-aika tarkoittaa väliaikaisen oleskeluluvan myöntämistä ihmiskaupan uhrille, jolta pysyvä oleskelulupa puuttuu. Harkinta-ajan tarkoitus on auttaa uhria ja rohkaista uhria yhteistyöhön viranomaisten kanssa. Niiden maiden, jotka ovat allekirjoittaneet Euroopan neuvoston yleissopimuksen, täytyy myöntää ihmiskaupan uhrille harkinta-aika, mutta harkinta-ajan pituus sekä perusteet sen myöntämiselle voivat vaihdella maiden välillä. Tutkimusten mukaan sekä pidemmissä että lyhemmissä harkintaajoissa on hyvät puolensa. Lyhemmät jaksot täyttävät poliisien tarpeet kun taas pidemmät jaksot ovat uhrin kannalta parempia. Yhteenvetona Brunovskis totesi, että harkinta-ajoissa ja sen erilaisissa malleissa oli sekä hyviä että huonoja puolia. Ajanjaksoja pidettiin kompromissiratkaisuna paremman puutteessa. 


\section{Suositukset}

- On tärkeää, että kaikki toimijat, jotka ovat tekemisissä ihmiskaupan uhrien kanssa, osaavat tunnistaa heidät ja hakea uhrille harkinta-aikaa.

- On tärkeää löytää tapapaino sen suhteen, että uhrille tarjotaan apua ja samalla varmistetaan, että uhrit tekevät yhteistyötä viranomaisten kanssa. Joillakin uhreilla voi olla erittäin vähän tietoa syyllisistä, mutta tämä ei saa estää heitä saamasta apua.

\subsection{Kommenttipuheenvuoro}

\section{Asianajaja Emilia Kaikkonen, Asianajotoimisto Matti Penttinen Oy, Helsinki, Suomi}

Asianajaja Emilia Kaikkonen kertoi kokemuksistaan, jotka liittyivät oikeudenkäynteihin, joissa hän on avustanut ihmiskaupan uhreja. Kaikkonen nosti muun muassa esille, että uhrit kunnioittavat auktoriteetteja ja useilla heistä on tunne siitä, että "pienistä" ongelmista ei saa valittaa. Lisäksi monet kokevat kiusalliseksi sen myöntämisen, että on tullut hyväksikäytetyksi. Kaikkonen totesi myös, että uhreista ei tunnu merkittävältä asialta, kuinka rangaistusprosessissa käy. Uhrien tarve on paljon käytännöllisempi; esimerkiksi turvallisen asunnon saaminen. Apu, jota asianajajat voivat ensisijaisesti tarjota uhrille, littyy oleskeluluvan hakemiseen, korvauksen vaatimiseen ja palkkavaatimusten esittämiseen.

\section{Suositukset}

- On tärkeää, että uhrille tarjotaan aina oikeusapua.

- Kuulustelun onnistumiseksi sen aikana esitutkinnassa tarvitaan oikea kuulustelutekniikka ja oikeita kysymyksiä. Hyödyntämällä erilaisia esitutkintametodeja ja pakkokeinoja voi saada todistuksia, jotka takaavat paremman menestyksen oikeudessa.

- Eri osapuolet tarvitsevat laajempaa tietoa ihmiskaupan tunnusmerkistöstä.

- Asennemuutosta ihmiskaupan ja sen uhrien aseman suhteen tarvitaan. Yleinen käsitys on, että uhrin olisi pitänyt ottaa selvää työehdoista. 


\subsection{Istunnon suositukset}

- Lisää tutkimusta ihmiskaupasta faktojen saamiseksi.

- Lisää koulutusta ihmiskaupan uhrien tunnistamiseksi.

- Lisää ehkäiseviä toimenpiteitä tarvitaan, esimerkiksi kysynnän vähentämiseksi.

- Uhrille tarjottava apu on tärkeää - uhrin oikeusavun tarjoaminen, tiedon antaminen yhteiskunnasta ja kotiin palaamisen mahdollisuuden tarjoaminen.

- Yhteistyön lisääminen eri toimijoiden välillä uhrin kotimaassa ja vastaanottavassa maassa.

Kuva 3. Osallistujat kuuntelevat tarkkaavaisesti istunnon Noudattavatko Pohjoismaat omia oppejaan? puhujia

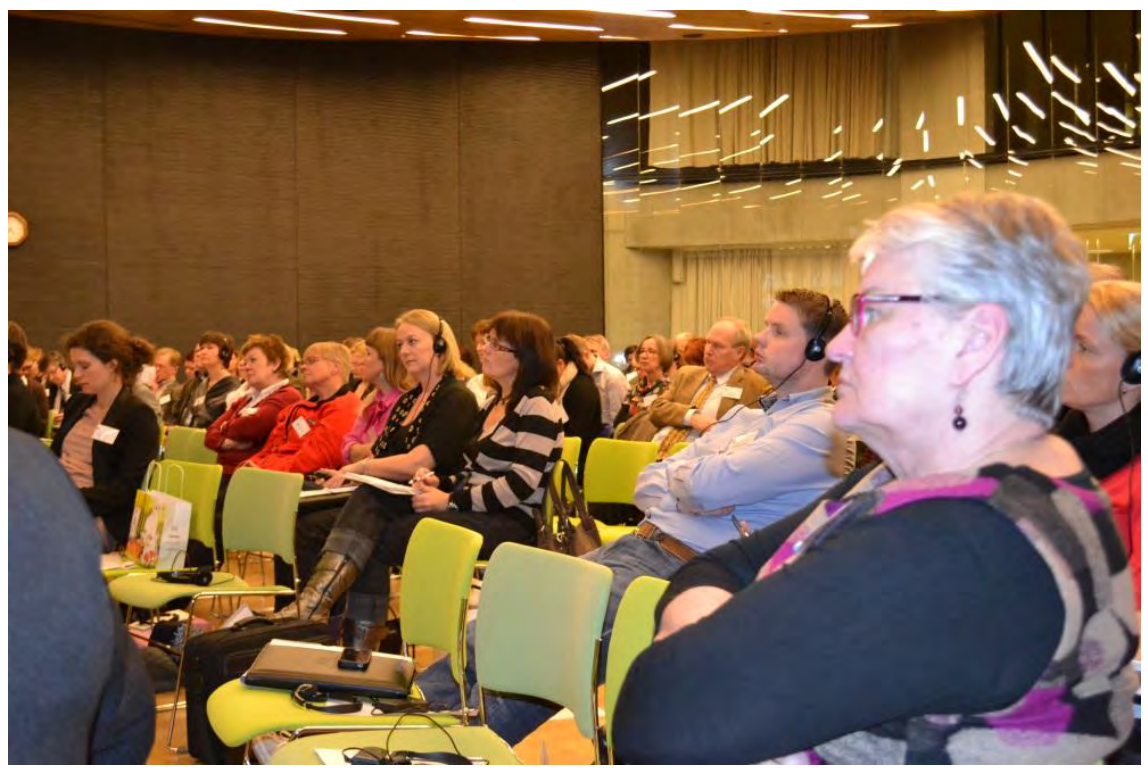

Valokuvaaja: Matti Keränen. 



\section{Istunto V Paneelikeskustelu Yhteistyötä yli rajojen ja sektoreiden}

\section{Puheenjohtaja}

Måns Enqvist Ylitarkastaja, Vähemmistövaltuutetun toimisto, Helsinki, Suomi.

\section{Paneeli}

- Vanhempi erityisasiantuntija Maria-Pia de Palo, Pohjoismainen ministerineuvosto.

- Syyttäjä Christina Voigt, Kansainvälinen syyttäjävirasto,Tukholma, Ruotsi.

- Tutkinnajohtaja Trine Møller, Kööpenhaminan poliisi, Tanska.

- Poliisitarkastaja Berglind Eyjólfsdóttir, Reykjavikin poliisi, Islanti.

- Yksikönjohtaja Arto Moksunen, Crossroads, Tukholma, Ruotsi.

- Koulutuspoliittinen asiantuntija Mikko Koskinen, Palvelualojen ammattiliitto PAM ry, Helsinki, Suomi.

Jokaista panelistia pyydettiin kertomaan hyvistä ihmiskaupan vastaisista kokemuksista ja keinoista. Jäljempänä jäsenten esittämiä ehdotuksia.

\section{Christina Voigt}

Valtamedian kautta tulee pyrkiä muokkaamaan asenteita ihmiskauppaa vastaan. Esimerkiksi Ruotsissa tiedotusvälineet kiinnittivät huomionsa marjanpoimijoihin, mikä vaikutti asenteisiin. Asennemuutos helpotti ihmiskauppaepäilyjen tutkimista ja ihmiskaupan uhrien tunnistamista. 


\section{Mikko Koskinen}

Myös ammattiliitot voisivat tehdä Ruotsin Crossroads-järjestön kaltaista työtä, eli laajaa yhteistyötä eri toimijoiden kanssa. Ammattiliitoissa tarvitaan ajattelutapojen muutosta. Ammattiliitoille kuuluu myös kaikkein haavoittuneimpien ammattiryhmien oikeuksien valvonta. Ammattiliitoissa tarvitaan uudenlaista ajattelua työelämän uusista piireteistä.

\section{Trine Møller}

Tarvitaan uudenlaista ajattelua ja vanhojen ajattelumallien hylkäämistä, jotta saadaan enemmän ihmiskauppatapauksia oikeuslaitoksen käsiteltäväksi.

\section{Maria-Pia de Palo}

Alueellinen ja Pohjoismaisen monialaisen yhteistyö sekä lähtö- ja vastaanottomaan välinen yhteistyö ovat tärkeitä. On myös tärkeä tarkastella ihmiskauppaa sukupuolten tasa-arvon näkökulmasta, koska miehet ja naiset tarvitsevat erilaista tukea ja erilaisia palveluita.

\section{Berglind Eyjólfsdóttir}

Islannin vähäisten ihmiskauppakokemusten vuoksi on tärkeää, että Islannissa seurataan ja opitaan naapurimaiden kokemuksista. Pohjoismaisen yhteistyön on tärkeä ihmiskaupan torjumisessa.

\section{Arto Moksunen}

Kontaktien solmimiinenen ja yhteistyö Eurooppalaisella tasolla on tärkeä. Crossroadsin kaltainen viranomaisten ja kansalaisjärjestöjen yhteistyö on hyvä esimerkki yhteistyöverkostosta. Kukaan ei voi ratkaista ihmiskaupan ongelmia yksin. 
Kuva 4. Ylitarkastaja Måns Enqvist johti panelikeskustelua. Paneliin osallistuivat (vasemmalta) syyttäjä Christina Voigt, Ruotsi, koulutuspoliittinen asiantuntija Mikko Koskinen, Suomi, vanhempi erityisasiantuntija Maria-Pia de Palo, Pohjoismaiden ministerineuvosto, tutkinnanjohtaja Trine Møller, Tanska, poliisitarkastaja Berglind Eyjólfsdóttir, Islanti ja yksikönjohtaja Arto Moksunen, Ruotsi

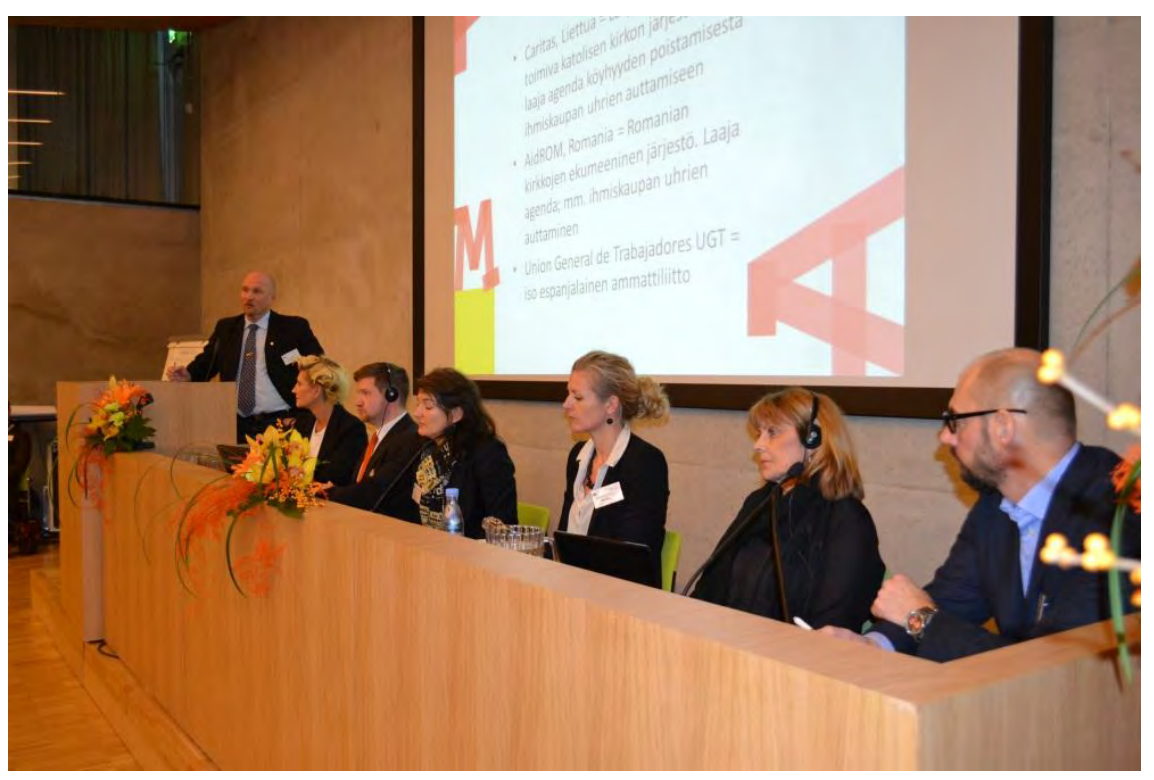

Valokuvaaja: Matti Keränen. 



\section{Yhteenveto ja loppupuheenvuoro}

Vähemmistövaltuutettu Eva Biaudet kokosi yhteen konferenssin antia ja konferenssin keskeisimmät päätelmät.

Ihmiskaupan uhrien tunnistaminen on haastavaa. Uhrien paremmaksi tunnistamiseksi ihmiskaupan kanssa tekemisiin joutuvia on koulutettava.

Biaudet korosti, että ihmiskaupan uhreille annettava harkinta-aika oikeusprosessin aloittamiseksi on tarkoitettu myös uhrin toipumiseen. Uhria ei saa painostaa aloittamaan yhteistyötä viranomaisten kanssa vain oikeusjutun edistämiseksi.

Eri sukupuolten tarpeet on huomioitava auttamisjärjestelmässä. Miehet tarvitsevat erilaista apua kuin naiset.

Avustaminen ei saa rajoittua koskemaan vain tunnistettuja uhreja. Tarvitaan Crossroadsin kaltaisia kansalaisjärjestöjen ja viranomaisten yhteenliittymiä uhrien auttamiseksi ja ihmiskaupan tunnistamiseksi. Yhteenliittymissä myös ne heikommassa asemassa olevat, joita ei ole tunnistettu ihmiskaupan uhreiksi, saavat apua yhteiskuntaan integroitumiseksi.

Lainsäädännön toimivuuden arvioimiseksi tarvitaan kansallinen ihmiskaupparaportoija tai vastaava taho, joka kykenee analysoimaan nykytilanteen ja nostamaan esille ongelmakohtia.

Jotta voidaan hyödyntää ja kehittää pohjoismaista ja kansainvälistä yhteistyötä, on muistettava, että ihmiskauppa on luonteeltaan samanlaista kaikkialla riippumatta mallista, jolla kukin maa pyrkii ihmiskauppaa torjumaan. 



\section{Yhteenveto suosituksista}

\subsection{Yleiset}

- Tietoisuus työperäisestä ihmiskaupasta on tällä hetkellä heikko. Ongelma on priorisoitava ja tietoisuutta on lisättävä tunnistamisen parantamiseksi. Tämä vaatii poliittista halua.

- Tulee ymmärtää, että pakkotyö on osa maahanmuuttorikollisuutta.

- Ihmiskauppa ja työvoiman hyväksikäyttö tulisi nähdä samassa kontekstissa, jossa toisessa päässä on lievempi hyväksikäyttö ja toisessa päässä vakavampi. Kaikissa tapauksissa ei ole kyse ihmiskaupasta, mutta pitää ymmärtää että riskinä hyväksikäyttötilanteissa on hyväksikäytön muuttuminen vakavaksi.

- Tarvitaan asenteenmuutos ihmiskaupasta ja uhrin asemasta yleisön keskuudessa. Yleinen käsitys on, että uhrin olisi pitänyt selvittää itse työehdot.

- Lisää koulutusta poliiseille, rajavartioille, työsuojeluviranomaisille sekä sosiaali- ja terveysalan työntekijöille ihmiskaupan uhrien tunnistamisessa. Tiedonvaihto ja yhteiset pelisäännöt on tehokkaan tunnistamisen edellytys.

- Ihmisarvon ja ihmisoikeuksien kunnioitus uhrien kohtelussa, auttamisjärjestelmän kehitys sekä parempi uhrin seuraaminen uudelleen uhriutumisen estämiseksi.

- Sukupuolten erilaiset tarpeet avustustilanteissa on huomioitava. Miehet ja naiset tarvitsevat erilaista apua ja palveluja. Tärkeää on pyrkiä tarjoamaan apua ja palveluista myös uhrin tarpeiden mukaan.

- Ihmiskauppaa tulisi pyrkiä estämään jo rajalla.

- Kysyntää tulisi vähentää.

- Keskustelu oleskeluluvista tulisi lisätä.

- Ihmiskauppatutkimusta tulisi lisätä faktojen saamiseksi. 


\subsection{Rekrytointi ja valvonta}

- Viranomaisten yhteistyötä rekrytointifirmojen ja työpaikkojen valvonnassa ja tarkastustoiminnassa tulisi lisätä työvoiman hyväksikäytön vähentämiseksi ja kiinnijäämisriskin lisäämiseksi.

- Palvelun loppukäyttäjien vastuuta pitää vahvistaa. Elintarviketeollisuuden tulisi ottaa vastuun marjanpoimijoiden työehtojen seurannassa.

- Viranomaisten pitäisi seurata marjanpoimintamatkoja paremmin ja marjanpoimijoiden riippuvuutta rekrytoinnin rahoittamisesta pitäisi vähentää. Todellisia tuloja ja kuluja pitäisi voida seurata ja rekrytointikulut eivät saa nousta liian suuriksi. Riski pitäisi jakaa tasaisemmin marjanpoimijoiden, rekrytoijien ja marjayritysten välillä.

- Marjanpoimijoita pitäisi informoida paremmin marjanpoiminnan työehdoista heidän omalla kielellään jo kotimaassa lupaprosessin yhteydessä.

- Ottaa käyttöön järjestelmä, jonka mukaan kaikki työntekijät kantaisivat veronumerolla varustetun henkilöllisyyskortin.

- Säännöllinen ja kattava seuranta työpaikoilla myös ennaltaehkäisevässä muodossa. Tarkastuksissa voidaan valistaa työntekijöitä laeista ja työehtosopimuksesta, sekä työntekijän oikeuksista ja työnantajan velvollisuuksista.

- Yksinkertaisemmat säännöt työperäiseen maahanmuuttoon.

\subsection{Oikeudelliset prosessit}

- Perustetaan ihmiskauppaan erikoistunut esitutkintaviranomainen.

- Vahva yhteistyö poliisin, syyttäjän ja työsuojeluviranomaisen välillä.

- Matala kynnys toiminnan ja strategioiden uudistamiseksi. On uskallettava puuttua ongelmaan eikä saa luovuttaa, vaikka prosessi on vaikea ja raskas.

- Nopeammat esitutkinnat. 
- Kuulustelujen onnistumiseksi niiden aikana esitutkinnassa tarvitaan oikea kuulemistekniikka ja oikeat kysymykset. Hyödyntämällä erilaisia esitutkintametodeita ja pakkokeinoja voidaan saada todisteita, jotka varmistavat paremman menestyksen oikeudessa.

- On oltava herkkä sille, mitä uhrit kertovat. Yhteneväiset kertomukset muodostavat ihmiskauppakaavan. Muista: "I will only tell my story if you care about it" (uhrin aseman ymmärtäminen).

- On tärkeää eristää rikoksentekijä ja uhrit toisistaan, ihmiskaupan uhrien apujärjestelmällä tai pidättämällä rikoksentekijä.

- On tärkeää löytää tasapaino avuntarjoamisen sekä uhrin ja viranomaisten välisen yhteistyön suhteen. Joillakin uhreilla voi olla vain vähän tietoa syyllisistä, ja tämä ei saa estää heitä saamasta apua.

- Asiantuntijatodistajien käyttäminen oikeudenkäynnissä.

- Simultaanitulkkauksen käyttö on toteutettava oikeudenkäyntien aikana käsittelyajan lyhentämiseksi.

- Perustetaan kansallinen työryhmä ("Task Force").

- Poliisille raportoimisen kynnystä on madallettava.

- Useat osapuolet tarvitsevat syvempää tietoa ihmiskaupan tunnusmerkistön sisällöstä.

- Harmaantalouden torjuntaa tulisi kehittää.

\subsection{Yhteistyö}

- Poikkihallinnollinen ja -alueellinen yhteistyö on välttämätöntä ihmiskaupan torjunnassa. Ihmiskauppa ei ole yksittäisen maan asia vain kansallisten toimien avulla ei voida taistella ihmiskauppaa vastaan.

- Viranomaisyhteistyötä tapahduttava kansallisella, pohjoismaisella ja kansainvälisellä tasolla.

- Yhteistyö työntekijän kotimaan ja kohdemaan viranomaisten välillä.

- Pohjoismainen yhteistyö tiedon jakamiseksi ihmiskaupan parissa työskentelevien syyttäjien välillä.

- Useiden osapuolien on tehtävä yhteistyötä jo työvoiman rekrytoinnista lähtien (teollisuus, ammattiyhdistykset, viranomaiset).

- Eri alojen välinen tiedonjakaminen ja dokumentointi. 
Kuva 5. Vähemmistövaltuutettu Eva Biaudet esitti yhteenvedon ja konferenssin loppupuheenvuoron

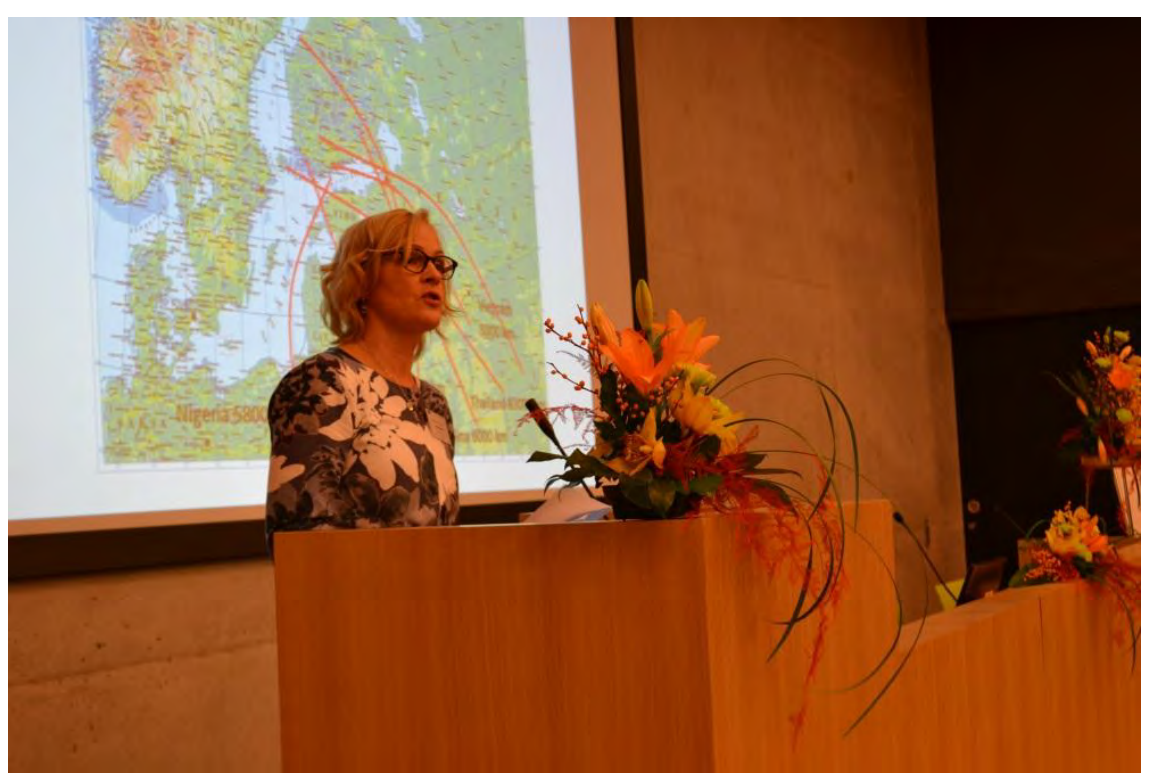

Valokuvaaja: Matti Keränen. 


\section{Sammanfattning}

Den nordiska konferensen om Människohandel med fokus på arbetsliv arrangerades i Helsingfors, Finland den 27-28.11.2012. På konferensens diskuterades problemställningar som är kopplade till människohandel i arbetslivet ur ett tvärsektoriellt perspektiv. Målet var att förmedla information om olika aktörers kunnande, roller, ansvar och förmåga att identifiera och hantera problemen kring arbetsrelaterad människohandel.

Största utmaningen för de olika aktörerna i Norden idag är att identifiera de personer, kvinnor, män, flickor och pojkar, som är offer för arbetsrelaterad människohandel. Det är viktigt att offren erhåller information om sina rättigheter och om de sociala tjänster som finns tillgängliga för dem. På konferensen presenterades praktiska exempel på hur de nordiska länderna, polisen, åklagare, domstol, arbetarskyddsförvaltning, arbetsmarknadsparter och NGOs arbetar med människohandel kopplat till arbetsmarknaden i Norden.

Konferensens utgångspunkt var de resultat och erfarenheter från projekt och konferenser, som genomförts kring prolemställningar om människohandel och arbetsliv under de senaste åren i Nordiska ministerrådet och av myndigheter och organisationer i Norden.

Frågeställningar, som diskuterades på konferensen var:

- Vad är skillnaden mellan att bli tvingad att arbeta och de dåliga arbetsvillkor, som en del invandrare hamnar i?

- Vad är den största utmaningen gällande identifieringen av offer för människohandel inom arbetsmarknaden?

- Vad kan arbetarskyddet bidraga med?

- Hur kan samarbetet mellan myndigheter och arbetsmarknadens parter effektiveras? Vilka är de största utmaningarna?

- Är de sociala tjänsterna anpassade till offrens behov?

- Vad uppnås genom ett nordiskt samarbete? 
Under konferensen arrangerades:

- en öppningssession

- fyra tema sessioner:

Till Norden - rekrytering av arbetskraft, Människohandel - utnyttjande av arbetskraft i Norden, Rättsliga processer - människohandel och

arbetsliv och Lever Norden som den lär?

- en paneldiskussion

Konferensen avslutades med en sammanfattning av minoritetsombudet Eva Biaudet.

Alla talare under sessionerna och deltagarna i paneldiskussionen presenterade rekommendationer om vilka åtgärder och insatser, som behövs i framtiden för att bekämpa människohandel. Rekommendationerna finns i samband med de enskilda presentationerna. I slutet av konferensrapporten finns en sammanfattning rekommendationerna som presenterades under konferensen.

Konferensen samlade ett stort antal deltagare från olika länder och organisationer. Sammanlagt deltog ca 260 personer i konferensen. Deltagarna kom från alla de nordiska länderna samt de baltiska länderna och NV Ryssland. Utav dessa var ca 70 poliser eller gränsbevakare. Övriga grupper som var representerade var politiker, internationella organisationer, åklagare, migrationsmyndigheter, arbetarskydds-myndigheter, arbetsmarknadsorganisationer, medborgarorganisationer och forskare.

Konferensen arrangerades av Minoritetsombudet i Finland, som också är nationell rapporteur för människohandel i Finland. Konferensen finansierades av Nordiska ministerrådet i samarbete med Minoritetsombudet i Finland och Nordiska rådet. 


\section{Summary}

The Nordic conference on Human Trafficking and Working Life was arranged in Helsinki, Finland 27-28.11.2013. The Nordic conference focused on how people today become victims of human trafficking as they seek jobs in foreign countries. The aim of the conference was to raise awareness of problems attached to this form of human trafficking in the Nordic countries through a diversified perspective.

The greatest challenge for Nordic stakeholders today is to identify the persons - women, men, girls and boys - who are victims of labour trafficking. It is also important that victims receive information about their rights, and about the social services that are available to them. A key question is how to adapt social services to the needs of the victims. At the conference practical examples was presented of how the Nordic countries, police, prosecutors, courts, occupational safety authorities, labour market organizations and NGOs' work with issues concerning human trafficking and the labour market in the Nordic countries.

The conference was built on the results and experiences obtained from other recent conferences and projects undertaken by Nordic Council of Ministers and authorities and organizations in the Nordic countries on the subject of human trafficking and working life.

Important questions discussed during the conference were:

- What is the difference between being forced to work and the poor working conditions some immigrants face?

- What is the greatest challenge in terms of identifying victims of trafficking at the labour market?

- How can the occupational safety authorities contribute?

- How can co-operation between the authorities and labour market organizations be intensified? Which are the greatest challenges?

- Are the social services consistent with the needs of the victims?

- What can be achieved through Nordic co-operation? 
During the conference was arranged:

- An opening session

- Four theme sessions

To the Nordic countries - recruiting labour force, Human trafficking exploitation of the labour force in the Nordic countries, Legal proceedings - human trafficking and the labour market and Do the Nordic countries practise what they preach?

- A panel discussion

Ombudsman for Minorities Eva Biaudet closed the conference by giving a summary of the conference.

All speakers presented recommendations for future actions and measures to combat labour trafficking. The speakers' recommendations are included in their presentations. In the end of the conference report is a summary of the recommendations presented at the conference.

The conference drew approximately 260 participants from different countries and organizations throughout the Nordic countries, the Baltic countries and Russia. Included among the participants were 70 representatives from police/law enforcement and border security. Other participants included politicians, international organizations, public prosecutors, immigration authorities, occupational health and safety authorities, trade unions and employer's organizations, NGOs and researchers.

The conference was arranged by the Ombudsman for Minorities in Finland. The conference was financed by the Nordic Council of Ministers in co-operation with the Ombudsman for Minorities in Finland and the Nordic Council. The Ombudsman for Minorities is the national rapporteur on trafficking in human beings in Finland. 


\section{Liite}
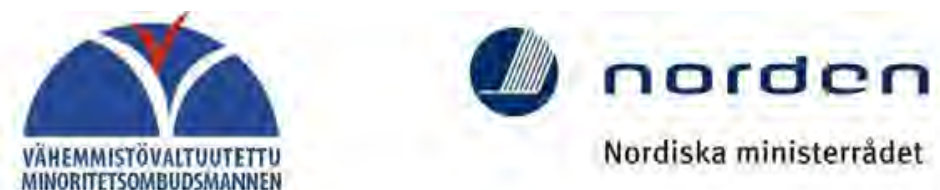

Nordiska ministerrådet

\section{POHJOISMAINEN KONFERENSSI IHMISKAUPASTA JA}

\section{TYÖELÄMÄSTÄ}

Sirkus-sali, Paasitorni, Paasivuorenkatu 5, Helsinki

27. -28.11 .2012$

Konferenssissa käsitellään monialaisesta näkökulmasta ihmisen joutumista ihmiskaupan uhriksi etsiessään töitä muista maista. Konferenssin tavoitteena on lisätä tietoa työperäisen inmiskaupan ongelmista Pohjoismaissa.

Suurin haaste ihmiskaupan vastaisessa työssä toimiville on tunnistaa ne naiset, miehet, tytöt ja pojat, jotka ovat työperäisen ihmiskaupan uhreja. Myös ihmiskaupan uhrien tiedonsaanti on keskeistä. Ihmiskaupan uhrien on saatava tietoa oikeuksistaan ja saatavilla olevista sosiaalisista palveluista. Tärkeä kysymys on, miten hyvin sosiaaliset palvelut on muokattu uhrien tarpeiden mukaan

Tavoitteena on välittää tietoa eri toimijoiden osaamisesta, rooleista ja vastuusta sekä kyvystä tunnistaa ja käsitellä työperäiseen ihmiskauppaan liittyviä ongelmia. Konferenssin lähtökohtana ovat tulokset aiemmista ihmiskaupan ja työelämän konferensseista ja projekteista, joita pohjoismaiset viranomaiset ja järjestöt ovat järjestäneet viime vuosina.

Konferenssin aikana esitellään käytännön esimerkkejä siitä, miten pohjoismaat, poliisi, syyttäjä, tuomioistuin, työsuojeluviranomaiset, työmarkkinatahot ja kansalaisjärjestöt työskentelevät työperäisen ihmiskaupan parissa.

Konferenssin aikana käsiteltäviä tärkeitä kysymyksenasetteluja ovat:

- Mikä on työhön pakottamisen ja joidenkin maahanmuuttajien kohtaamien huonojen työehtojen välinen ero?

- Mikä on suurin haaste liittyen ihmiskaupan uhrien tunnistamiseen työmarkkinoilla?

- Miten työsuojelu voi myötävaikuttaa?

- Kuinka yhteistyötä viranomaisten ja työmarkkinoiden osapuolten välillä voidaan tehostaa? Mitkä ovat suurimmat haasteet?

- Onko sosiaalisia palveluita mukautettu uhrien tarpeisiin?

- Mită voidaan saavuttaa pohjoismaisella yhteistyöllä?

Konferenssin kielinä ovat skandinaaviset kielet. Tulkkausta järjestetään suomen, englannin ja venäjän kielelle.

Konferenssin järjestää Suomen vähemmistövaltuutettu yhteistyössä Pohjoismaiden ministerineuvoston ja Pohjoismaiden neuvoston kanssa. Konferenssi on Pohjoismaiden ministerineuvoston ja Pohjoismaiden neuvoston rahoittama. Vähemmistövaltuutettu on kansallinen ihmiskaupparaportoija Suomessa. 


\section{OHJELMA}

\section{TIISTAI 27.11.2012}

11.30 Rekisteröityminen ja lounas

\subsection{KONFERENSSIN AVAUS}

Puheenjohtaja: Vähemmistövaltuutettu Eva Biaudet, Suomi

Ministeri Anna-Maja Henriksson, Oikeusministeriö, Suomi

Pääsihteeri, Halldor Asgrimsson, Pohjoismaiden

ministerineuvosto

Kansanedustaja Satu Haapanen, Eduskunta, Suomi, sekä

Kansalais- ja kuluttajavaliokunnan puheenjohtaja,

Pohjoismaiden neuvosto

13.30 Ihmiskauppa - mikä on pakko, mitä on hyväksikäyttö?

Vähemmistövaltuutettu Eva Biaudet, Suomi

\subsection{ISTUNTO I: POHJOISMAIHIN - TYÖVOIMAN \\ REKRYTOINTI}

Puheenjohtaja: Vanhempi erityisasiantuntija Anna Ekstedt, Itämeri-neuvosto (CBSS)

Sairaanhoitajien rekrytointi Ullevålin sairaalaan Oslossa

Poliisitarkastaja Bjørn Vandvik, Oslon poliisipiiri, Norja

Ulkomaalaiset marjanpoimijat Suomessa

Tutkija Pekka Rantanen, Tampereen yliopisto, Tampere, Suomi

Au-paireihin ja siivousalaan kohdistuva ihmiskauppa - riskit, rekrytointi ja välittäjät

Antropologi, fil.toht, stipendiaatti Trine Mygind Korsby,

Antropologian laitos, Kööpenhaminan yliopisto, Kööpenhamina, Tanska

Kommenttipuheenvuoro: II. puheenjohtaja Kyösti Suokas,

Rakennusliitto, Suomi

Keskustelua

15.30 Kahvitauko

\subsection{ISTUNTO II: IHMISKAUPPA - TYÖVOIMAN \\ HYVÄKSIKÄYTTÖ POHJOISMAISSA}

Puheenjohtaja: Kansanedustaja Maria Stenberg, Kansalais- ja

kuluttajavaliokunta, Pohjoismaiden neuvosto, Ruotsi

Työvoiman maahanmuutto Itä- ja Keski-Euroopasta

Pohjoismaihin: kaavat, työolosuhteet ja rekrytointi

Tutkija Line Eldring, Työelämän- ja hyvinvoinnin tutkimuslaitos

(FaFo), Oslo, Norja

Ihmiskauppiaat - veroviraston toimet ihmiskauppaa vastaan

John Vorbeck Petersen, Talousrikokset, Verovirasto, Tanska

Ammattiyhdistysten toimet työmarkkinoilla tapahtuvaa

ihmiskauppaa vastaan Pohjoismaissa Tutkija Thord Ingesson,

LO, Ruotsi

Kommenttipuheenvuoro: Tarkastaja Kristiina Linna, Työsuojelun vastuualue, Lounais-Suomen aluehallintovirasto, Suomi

Keskustelua 
17.30 Lopetus ja yhteenveto

Vähemmistövaltuutettu Eva Biaudet, Suomi

18.30 Vastaanotto

Säätytalo, Snellmaninkatu 9-11, Helsinki

\section{KESKIVIIKKO 28.11.2012}

\subsection{ISTUNTO III: OIKEUDELLISET PROSESSIT - \\ IHMISKAUPPA JA TYÖELÄMÄ}

Puheenjohtaja: Erikoissuunnittelija Natalia Ollus, YK:n

yhteydessä toimiva Euroopan kriminaalipolitiikan instituutti (HEUNI), Suomi

Norjalainen oikeustapaus - syyttäjän ja poliisin välinen yhteistyö

Tutkinnanjohtaja Jarle Bjørke, Bergenin poliisipiiri, Norja

Ihmiskauppa marjanpoimijoilla - marjanpoimijoiden rekrytointi Ruotsiin

Syyttäjä Christina Voigt, Kansainvälinen syyttäjävirasto, Tukholma, Ruotsi

Työperäinen ihmiskauppa - esitutkinnan ja prosessin haasteet syyttäjän näkökulmasta

Johtava kihlakunnansyyttäjä Peter Levlin, Pohjanmaan

syyttäjälaitos, Suomi

Kommenttipuheenvuoro: Islanti

Komissaario Sigriður Björg Guðjónsdóttir, Suðurnen poliisipiiri,

Keskustelua

11.00 Kahvitauko

\subsection{ISTUNTO IV: NOUDATTAVATKO POHJOISMAAT OMIA \\ OPPEJAAN?}

Puheenjohtaja: Korkeakoululehtori ja stipendiaatti Birgitte

Ellefsen, Poliisikorkeakoulu, Norja

Unelma koulutuksesta ja työstä

Sirle Blumberg, Living for Tomorrow, Viro

Uhrien harkinta-ajat - kokemuksia seitsemästä maasta

Tutkija Anette Brunovskis, Työelämän- ja

hyvinvoinnintutkimuslaitos ( $\mathrm{FaFo}$ ) Norja

Kuka tulee työskentelemään Ruotsiin?

Osastonjohtaja Arto Moksunen, Crossroads, Ruotsi

Kommenttipuheenvuoro: Asianajaja Emilia Kaikkonen, Suomi

Keskustelua

13.00 Lounas

\subsection{ISTUNTO V: PANEELIKESKUSTELU - YHTEISTYÖTÄ YLI RAJOJEN JA SEKTOREIDEN}

\subsection{KONFERENSSIN PÄÄTÖS JA YHTEENVETO}

Vähemmistövaltuutettu Eva Biaudet, Suomi 
Pohjoismaiden ministerineuvosto

Ved Stranden 18

DK-1061 København K

www.norden.org

Ihmiskauppa ja työelämä

Pohjoismaisessa konferenssissa Ihmiskaupasta ja työelämästä käsiteltiin monialaisesta näkökulmasta ihmisen joutumista ihmiskaupan uhriksi etsiessään töitä muusta maasta. Konferenssin tavoitteena oli lisätä tietoa työperäisen ihmiskaupan ongelmista Pohjoismaissa.

Suurin haaste ihmiskaupan vastaisessa työssä toimiville on tunnistaa ne naiset, miehet, tytöt ja pojat, jotka ovat työperäisen ihmiskaupan uhreja. Myös ihmiskaupan uhrien tiedonsaanti on keskeistä. Ihmiskaupan uhrien on saatava tietoa oikeuksistaan ja saatavilla olevista sosiaalisista palveluista ja miten hyvin sosiaaliset palvelut on muokattu uhrien tarpeiden mukaan.

Konferenssissa välitettiin tietoa eri toimijoiden osaamisesta, rooleista ja vastuusta sekä kyvystä tunnistaa ja käsitellä työperäiseen ihmiskauppaan liittyviä ongelmia. Konferenssin lähtökohtana olivat tulokset aiemmista ihmiskaupan ja työelämän projekteista, joita pohjoismaiset viranomaiset ja järjestöt ovat järjestäneet viime vuosina.

Konferenssin aikana esiteltiin käytännön esimerkkejä siitä, miten Pohjoismaat, poliisi, syyttäjä, tuomioistuin, työsuojeluviranomaiset, työmarkkinatahot ja kansalaisjärjestöt työskentelevät työperäisen ihmiskaupan parissa.
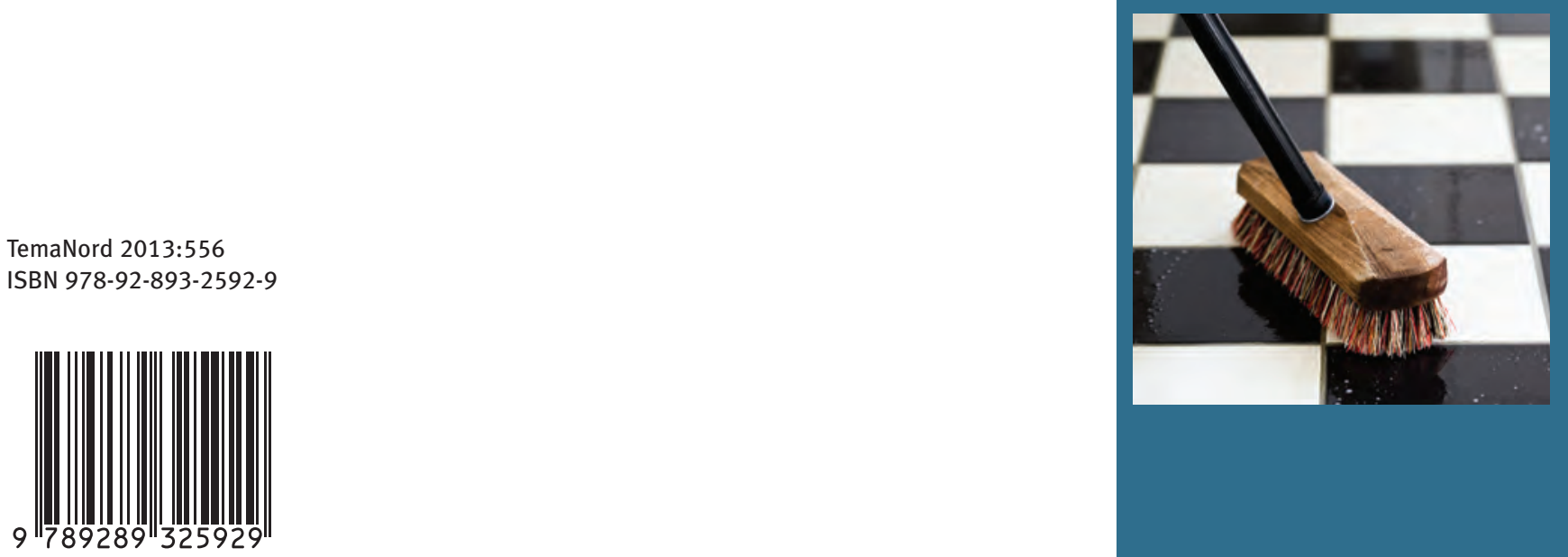